\title{
Development of Neurotransmitter Metabolism in Embryos of the Leech Haementeria ghilianii
}

\author{
Joel C. Glover, ${ }^{1, a}$ Duncan K. Stuart, ${ }^{2}$ Hollis T. Cline, ${ }^{2, b}$ Richard E. McCaman, ${ }^{3}$ Catherine Magill, ${ }^{2, c}$ and Gunther S. \\ Stent ${ }^{2}$ \\ 'Department of Biology, University of California, San Diego, California 92093, ${ }^{2}$ Department of Molecular Biology, University \\ of California, Berkeley, California 94720, and ${ }^{3}$ Section of Neuropharmacology, City of Hope, Duarte, California 91010
}

\begin{abstract}
We have investigated the development of neurotransmitter metabolism in embryos of the glossiphoniid leech Haementeria ghilianii. The neurotransmitter content of dissected embryonic tissues was measured by means of radioenzymatic assays, while the presence of neurotransmitters in individual identified neurons was detected by means of immunocytochemical and monoamine histofluorescence techniques. The capacity for synthesis of neurotransmitters was measured by incubating dissected embryonic tissues in radiolabeled neurotransmitter precursors. A specific neurotransmitter uptake system present in some neurons was detected by means of an autoradiographic technique. At an early stage of development of the nervous system, when most neurons are just beginning process outgrowth, the nerve cord acquires the capacity to synthesize ACh, 5-HT, and GABA from their immediate precursors, and contains ACh. Moreover, 5-HT-immunoreactive neurons and neurons that are capable of GABA uptake can be identified. Dopamine-containing neurons are first detected by their histofluorescence at a slightly later stage, after process outgrowth is under way. As development continues, the content of and capacity for synthesis of these neurotransmitters increase, as does the number of neurons capable of GABA uptake. During the earlier stages of development, $\mathrm{ACh}$ content exceeds 5-HT content, which in turn exceeds dopamine content. By the end of embryogenesis, however, 5-HT and dopamine contents have greatly increased relative to $\mathrm{ACh}$ content, with 5-HT content exceeding ACh content by a factor of 2. Of the neurotransmitters thus far studied, 5-HT is present in the highest amount in the juvenile and adult nerve cord. Our results indicate that in the development of the leech nervous system neurotransmitter metabolism is one
\end{abstract}

\footnotetext{
Received May 12, 1986; revised Aug. 6, 1986; accepted Aug. 19, 1986.

We thank Judith Stetzler for expert technical assistance in the measurement of neurotransmitter contents and Tom Morrison for assistance in the measurement of the capacity for ACh synthesis of adult leeches. This research was supported by Postdoctoral Research Fellowship NS05996, Training Grant GM 07048, and Research Grants NS188857, NS20746, and NS12818 from the National Institutes of Health, a James E. Kelley Research Fellowship, and Research Grant BNS79. 12400 from the National Science Foundation.

Correspondence should be addressed to Gunther S. Stent at the above address.

a Present address: Institute of Physiology, University of Oslo, Karl Johans gate 47, 0162 Oslo, Norway.

b Present address: Department of Biology, Yale University, New Haven, CT 06511.

' Present address: Department of Neurobiology, Stanford University, Stanford, CA 94305 .

Copyright (C) 1987 Society for Neuroscience $0270-6474 / 87 / 020581-14 \$ 02.00 / 0$
}

of the first neuronal characters to differentiate and that the subsequent levels of the different neurotransmitters are differentially regulated.

The many substances that function as neurotransmitters in the nervous system reflect the chemical diversity of neuronal cell types. How does this diversity arise during embryonic development? The leech nervous system offers an opportunity to define at a cellular level the factors that govern neurochemical differentiation: Identifiable neurons can be characterized not only in the adult, but also in living preparations of the embryo, where their developmental line of descent and differentiation can be studied (Weisblat, 1981; Kramer and Weisblat, 1985).

The CNS of leeches consists of a nerve cord composed of 32 segmentally repeated, highly stereotyped ganglia, as well as of a nonsegmental supraesophageal ganglion. The rostral 4 and the caudal 7 segmental ganglia are fused to form the subesophageal and caudal ganglia, respectively; the intervening 21 ganglia are unfused and designated in rostrocaudal sequence as abdominal ganglia 1-21. The typical segmental ganglion contains 350-400 neurons, each potentially identifiable by such criteria as position, morphology, synaptic connections, function, and neurotransmitter content. The PNS includes some identified segmentally repeated neurons, as well as the axons and endings of effector and sensory neurons located in the segmental ganglion. The neurotransmitters whose presence (or capacity for synthesis) has been detected in the leech nervous system include $\mathrm{ACh}$, 5-HT, dopamine, octopamine, and GABA (Wallace, 1981). A set of 5-HT-containing and dopamine-containing neurons has been identified (Lent, 1982; Lent et al., 1983; Glover, 1986), as has been a set of neurons that contains ChAT activity and includes all known excitatory motor neurons (Wallace, 1981), and a set of GABAergic neurons that includes some known inhibitory motor neurons (Cline, 1983, 1986; Cline et al., 1985). In addition, neurons immunoreactive to antibodies directed against the neuropeptides Leu-enkephalin (Zipser, 1980), proctolin (Li and Calabrese, 1985), FMRFamide (Kuhlman ct al., 1984), substance $P$, somatostatin, vasoactive intestinal polypeptide, and Met-enkephalin (Leake et al., 1986), and hence containing either these peptides or immunoreactively similar antigens, have been identified.

Here we examine the time course of neurochemical differentiation during embryogenesis of the glossiphoniid leech $\mathrm{Hae}$ menteria ghilianii. Our results indicate that the embryonic neurons begin to develop the capacity for the synthesis and uptake of neurotransmitters early in the formation of the leech nervous system. Indeed, in some neurons this capacity seems to be among 
the first neuronal characteristics to differentiate. Our findings thus complement studies of the differentiation of other phenotypic traits that are characteristic of identified leech neurons (Kramer and Kuwada, 1983; Kuwada and Kramer, 1983; Kuwada, 1984).

\section{Materials and Methods}

\section{Animals}

Specimens of $H$. ghilianii were obtained from breeding colonies at the University of California, Berkeley, and at the University of California, San Diego. The procedures for maintaining these colonies and the collection and care of embryos have been previously described (Sawyer et al., 1981; Kuwada and Kramer, 1983). Embryos were raised at $27^{\circ} \mathrm{C}$ and staged according to a set of morphological criteria (Fernandez, 1980; Weisblat, 1981), employing Haementeria substages described previously (Kuwada and Kramer, 1983).

Haementeria leeches are protandrous hermaphrodites. Under conditions of laboratory culture they remain juveniles following their first and second feeding. Normally they become sexually active as males after their third feeding and become capable of laying eggs only after their fourth feeding (Sawyer et al., 1981).

\section{Dissections}

All dissections were carried out on embryonic, juvenile, or adult specimens pinned out in Sylgard-coated dishes containing Haementeria Ringer's solution $\left(130 \mathrm{~mm} \mathrm{NaCl}, 4.0\right.$ or $8.0 \mathrm{mM} \mathrm{KCl}, 1.8 \mathrm{mM} \mathrm{CaCl}_{2}$, and $1.8 \mathrm{mM} \mathrm{MgSO}_{4}$ ) buffered with $10 \mathrm{~mm}$ NaHEPES, pH 7.4 (Kuwada and Kramer, 1983). In the case of all embryos younger than stage 9(2/ 4), the dissection entailed an incision along the dorsal midline, followed by removal of yolk and provisional integument. The remaining tissue will be referred to as the "germinal plate." In the case of all embryos at or older than stage 9(3/4) and unfed juveniles, the nerve cord was dissected from the germinal plate, the remainder of which will be referred to as "body wall." In the case of embryos at stage $9(2 / 4)$, some were dissected as germinal plate preparations and others as nerve cord and body wall preparations. In the case of second- and third-fed specimens, single or paired segmental ganglia were dissected from the isolated nerve cord.

\section{Neurotransmitter assays}

Single adult ganglia, whole embryonic or juvenile nerve cords, embryonic body walls, or germinal plates were pooled for assay and placed in glass microtubes $(65 \mathrm{~mm}$ long, inner diameter of $5 \mathrm{~mm}$ tapering to 2 $\mathrm{mm}$ ) containing 20-40 $\mu \mathrm{l}$ (depending on amount of tissue) of ice-cold extraction medium ( $20 \mathrm{~mm}$ mercaptoacetic acid in $0.1 \mathrm{~N} \mathrm{HCl}$ ). The number of embryos chosen for pooling was based on the amounts of neurotransmitter measured in pilot experiments; in no case were more than 10 embryos used per pool. The pooled tissue was stored in the extraction medium at $-70^{\circ} \mathrm{C}$ for up to 2 weeks. No significant loss of neurotransmitters occurred during storage for this period. Each neurotransmitter assay of the adult nervous system was carried out on 2 ganglia dissected from a second-fed specimen weighing $0.7 \mathrm{gm}$ and from a third-fed specimen weighing $6.2 \mathrm{gm}$ (Sawyer et al., 1981). Since the content of neurotransmitter and of total protein per ganglion was found to be very similar for both specimens, the data from them were pooled for presentation in Table 1 .

To extract the transmitters, the frozen tissue was thawed and refrozen 3 times. Samples were then taken from the extract for radioenzymatic assay of ACh, 5-HT, dopamine, octopamine, and histamine. The assays have been described previously (in the order listed: McCaman and Stetzler, 1977; McCaman et al., 1984; McCaman et al., 1979; McCaman and McCaman, 1978; Weinreich et al., 1975). Each assay involves the stoichiometric enzymatic conversion of extracted neurotransmitter into a radiolabeled compound, which can be isolated and counted for its content of radioisolope. From most tissue extracts duplicate samples were taken for each assay performed. In one case [5-HT, embryonic stage $10(0)$ ], only a single determination was made. The neurotransmitter content of the total extract was calculated by multiplying the assay value of a sample by the ratio of extract volume to sample volume and correcting for recovery. In each set of assays there was an average recovery value of more than $85 \%$, except for the 5-HT assays of embryonic body walls, for which the average recovery was only $41 \%$.
The limit sensitivity of the assay is defined as twice the radioisotope counts contained in the assay blank, which consisted of $10 \mu \mathrm{l}$ of extraction medium (McCaman, 1971). Samples whose counts were less than, or equal to, the limit sensitivity are reported here as containing no neurotransmitter at all, although we also used the values of the limit sensitivity to estimate the maximum amount of neurotransmitter an extract reported to have no neurotransmitter could contain.

5-HT assay. The specificity of the radioenzymatic assay for 5-HT is based on the $\mathrm{N}$-acetylation of 5 -HT by $\mathrm{N}$-acetyltransferase and the radiolabeled methylation of the hydroxyl group by hydroxyindole- $O$ methyltransferase (with $S$-adenosylmethionine as a methyl donor) to produce the product ${ }^{3} \mathrm{H}-5$-methoxy- $N$-acetyltryptamine (melatonin). In this assay only $N$-acetylserotonin, an intermediate product in the assay, can mimic 5-HT. That extracts of juvenile and adult nerve cords did not, in fact, contain any endogenous $N$-acetylserotonin was demonstrated by omitting $N$-acetyltransferase from the reaction mixture of the assay and obtaining no radiolabeled melatonin. We assume that the assays of embryonic tissue similarly reflect only endogenous 5-HT.

$A C h$ assay. The specificity of the radioenzymatic assay for $\mathrm{ACh}$ is based on the tandem actions of 2 enzymes, AChE and choline phosphokinase. The former catalyzes the selective hydrolysis of $\mathrm{ACh}$ to acetate and choline and the latter the selective phosphorylation by ${ }^{32} \mathrm{P}$ labeled ATP of the choline product to yield radiolabeled phosphocholine. When assaying ACh in the vertebrate tissues, an additional step (liquid cation extraction) is necessary to remove a reactive tissue constituent that is not ACh (Goldberg and McCaman, 1973). As is the case for certain other invertebrate tissues (McCaman and Stetzler; 1977), this step can be omitted in the analysis of leech tissues, since preliminary experiments showed that the amount of ACh detected is the same with or without its inclusion.

Dopamine assay. The specificity of the radioenzymatic assay for dopamine is based on the tandem actions of the enzymes $\mathrm{N}$-acetyltransferase and catechol- $O$-methyl transferase. The first enzyme acetylates the dopamine to $\mathrm{N}$-acetyldopamine and the second enzyme, in the presence of radiolabeled $S$-adenosylmethionine, transfers a ${ }^{3} \mathrm{H}$-methyl moiety to a hydroxyl group of the ring to form ${ }^{3} \mathrm{H}$-methoxy- $\mathrm{N}$-acetyldopamine. The assay is specific for dopamine and $N$-acetyldopamine among a variety of catecholamines and amines. We did not assay Haementeria nervous tissue for the presence of endogenous $N$-acetyldopamine, by omitting the first enzyme, and hence the values reported here for dopamine content might include some endogenous $N$-acetyldopamine.

\section{Capacity for synthesis and accumulation of neurotransmitters}

The capacities of embryonic neurons to synthesize and accumulate ACh, 5-HT, or GABA were assayed by exposing germinal plates or nerve cords to the ${ }^{3} \mathrm{H}$-labeled precursors choline, 5-hydroxytryptophan, or glutamate, respectively (Hildebrand et al., 1971; Sargent, 1977). The ${ }^{3} \mathrm{H}$-labeled precursors, methyl- ${ }^{3} \mathrm{H}$-choline chloride $(6.4 \mathrm{Ci} / \mathrm{mmol}$, Amersham), DL-5-hydroxy-G- ${ }^{3} \mathrm{H}$-tryptophan ( $2 \mathrm{Ci} / \mathrm{mmol}$, Amersham), and $\mathrm{L}-3,4-{ }^{3} \mathrm{H}$-glutamic acid $(46 \mathrm{Ci} / \mathrm{mmol}$, New England Nuclear) were purified prior to use by high-voltage paper electrophoresis (Mains and Patterson, 1973). The dissected embryonic tissues to be assayed were placed in a $0.3 \mathrm{ml}$ conical cup (Sarsted No. 73.640) containing the radiolabeling reaction mixture in Haementeria Ringer's solution and incubated for $3 \mathrm{hr}$ at $27^{\circ} \mathrm{C}$.

ACh synthesis assay. A radiolabeling reaction mixture containing 0.08 mM choline was prepared by drying $5 \mu \mathrm{Ci}{ }^{3} \mathrm{H}$-labeled choline under nitrogen and redissolving it in $10 \mu \mathrm{l}$ of Haementeria Ringer's solution supplemented with $50 \mu \mathrm{M}$ eserine (Sigma). After incubation the labeled tissues were rinsed 3 times in Haementeria Ringer's solution supplemented with $50 \mu \mathrm{M}$ eserine. The radioactive reaction products were then extracted by suspending the labeled tissues in $15 \mu \mathrm{l}$ extraction solution (containing $0.5 \mathrm{mg} / \mathrm{ml} \mathrm{SDS}$, dissolved in electrophoresis buffer: $1.4 \mathrm{M}$ acetate, $0.47 \mathrm{M}$ formate, $\mathrm{pH}$ 1.9) supplemented with $20 \mathrm{mg} / \mathrm{ml}$ each of unlabeled choline and $\mathrm{ACh}$ as standards, as well as with $14 \mu \mathrm{g} / \mathrm{ml}$ eserine, and rapidly freezing and thawing the suspensions 5 times. The extract was then applied to Whatman No. 1 electrophoresis paper and subjected to high-voltage electrophoresis $(5 \mathrm{kV}, 1.5 \mathrm{hr})$, a procedure that separates cleanly the reaction product $\mathrm{ACh}$ from its precursor choline. After electrophoretic separation, the unlabeled standards were located by spraying the electrophoresis paper with a $1 \%$ solution of iodine in acetone. The radioactivity associated with the ACh standard was counted by cutting the stained region into strips of $1 \mathrm{~cm}$ and eluting the labeled $\mathrm{ACh}$ 
reaction product from the paper with $0.5 \mathrm{ml}$ of $0.1 \mathrm{~N} \mathrm{HCl}$ for $1 \mathrm{hr}$. The eluate was added to $5 \mathrm{ml}$ of Aquasol-2 (New England Nuclear) for scintillation counting. The total number of picomoles of reaction product synthesized and accumulated in the tissue was calculated by dividing the radioactivity counted in the eluate by the specific radioactivity of the ${ }^{3} \mathrm{H}$-labeled precursor in the incubation mixture. An ACh synthesis assay was also carried out on single or paired abdominal ganglia dissected from 2 second-fed leeches, one weighing $0.6 \mathrm{gm}$ and the other $0.8 \mathrm{gm}$.

5-HT synthesis assay. A radiolabeling reaction mixture containing $0.05 \mathrm{mM}$ DL-5-hydroxytryptophan was prepared by drying $5 \mu \mathrm{Ci}$ of ${ }^{3} \mathrm{H}-$ labeled DI-5-hydroxytryptophan under nitrogen and redissolving it in $50 \mu \mathrm{l}$ of Haementeria Ringer's solution. The same protocol as for the ACh synthesis assay was then followed, except that eserine was omitted from the extraction solution, that the latter was supplemented with 10 $\mathrm{mg} / \mathrm{ml}$ each of unlabeled 5-hydroxytryptophan and 5-HT as standards, and that after electrophoretic separation the standards were located by spraying the electrophoresis paper with a ninhydrin solution $[100 \mathrm{ml}$ of a $0.2 \%$ solution of ninhydrin in $100 \%$ ethanol, $10 \mathrm{ml}$ glacial acetic acid, and $10 \mathrm{ml}$ trimethylpyridine (Sigma)].

GABA synthesis assay. A radiolabeling mixture was prepared by dissolving $8 \mu \mathrm{Ci}$ of ${ }^{3} \mathrm{H}$-labeled glutamic acid in $10 \mu \mathrm{l}$ Haementeria Ringer's solution (fortified with a higher concentration of HEPES buffer to maintain $\mathrm{pH}$ 7.6) containing $10 \mathrm{~mm}$ nonlabeled glutamic acid. The same protocol was then followed as for the 5-HT synthesis assay, except that after incubation, $20 \mu \mathrm{l}$ of extraction solution, supplemented with 20 $\mathrm{mg} / \mathrm{ml}$ each of unlabeled glutamic acid and GABA as standards, was added directly to the incubation mixture. Thus, in contrast to the ACh and 5-HT synthesis assays, which measured only the amount of ${ }^{3} \mathrm{H}$ labeled neurotransmitter accumulated within the tissue, the GABA synthesis assay also included the amount released into the incubation mixture.

Protein assay. The total protein content of tissue samples equivalent to those analyzed in the neurotransmitter assays was determined by means of a modification of the Lowry procedure (Lowry et al., 1951; Peterson, 1977), with the following additional changes. Dissected tissue was pooled and transferred to $1.5 \mathrm{ml}$ propylene microcentrifuge tubes. For a given embryonic stage the amount pooled (up to 10 nerve cords or body walls) was chosen so that there would be at least $4 \mu \mathrm{g}$ of total protein. Protein was extracted from the tissue by addition of a $0.5 \%$ solution of Triton X-100 (Sigma) in $0.5 \mathrm{ml}$ of $0.5 \mathrm{~N} \mathrm{NaOH}$ and freezing at $-70^{\circ} \mathrm{C}$. The samples were thawed and neutralized with $0.5 \mathrm{ml}$ of 0.5 $\mathrm{N} \mathrm{HCl}$, the protein was precipitated with $100 \mu \mathrm{l}$ of $0.15 \%$ deoxycholate and $100 \mu \mathrm{l}$ of $72 \%$ trichloroacetic acid, and the pellet was resuspended in $200 \mu \mathrm{l}$ water. One milliliter of reagent $\mathrm{A}\left[1.3 \% \mathrm{Na}_{2} \mathrm{CO}_{3}, 1.3 \% \mathrm{SDS}\right.$ (Sigma), $0.012 \% \mathrm{CuSO}_{4} \cdot \mathrm{H}_{2} \mathrm{O}, 0.024 \%$ sodium citrate $\cdot 2 \mathrm{H}_{2} \mathrm{O}$, all in 0.11 $\mathrm{N} \mathrm{NaOH}$ ] was added to the suspension, followed by addition $10 \mathrm{~min}$ later of $0.1 \mathrm{ml}$ of Folin-Ciocalteu phenol reagent (Sigma, diluted to 0.67 N). After $30 \mathrm{~min}$ the light absorbance at $750 \mathrm{~nm}$ by the reaction mixture was measured. Dilutions of a Sigma protein solution $(5 \%$ human albumin and 3\% globulin) were subjected to the same assay procedure in triplicate to generate standard reference values.

\section{5-HT immunocytochemical assay}

Embryos were dissected to expose the nerve cord and fixed in $4 \%$ formaldehyde in $0.1 \mathrm{M} \mathrm{PBS}, \mathrm{pH} 7.4$, at $4^{\circ} \mathrm{C}$ overnight. The tissue was then rinsed several times with PBS containing $0.1 \%$ sodium azide and stored at $4^{\circ} \mathrm{C}$ for several days. To carry out the, immunocytochemical assay, the tissue was exposed at room temperature with continuous agitation for 9-10 hr to rabbit antiserum (Immunonuclear, lot no. 29311) raised against an antigen consisting of 5-HT coupled to BSA via formaldehyde (Steinbusch et al., 1978). The immunological reaction mixture consisted of a 500 -fold dilution of the anti-5-HT serum in PBS containing $1 \%$ BSA, $1 \%$ normal goat serum, and $2 \%$ Triton X-100. After the reaction the tissue was rinsed several times with PBS for a total of $1-3 \mathrm{hr}$, and then exposed for 7-12 hr to HRP-conjugated goat anti-rabbit serum (Cappel, lot no. 18040), diluted 250-fold in PBS containing 1\% BSA, $2 \%$ normal goat serum, and $2 \%$ Triton X-100. After the second immunological reaction, the tissue was rinsed in PBS, stained for HRP activity (Gillon and Wallace, 1984), dehydrated with ethanol, cleared in xylene, and mounted in Permount.

The specificity of the 5-HT antiserum used in this study is indicated by its labeling only those neurons in the leech that are known to contain 5-HT and that upon selective ablation of the 5-HT-containing neurons
Table 1. Neurotransmitter content of nerve cords of unfed juvenile and adult Haementeria

\begin{tabular}{llll} 
& ACh & 5-HT & Dopamine \\
\hline $\begin{array}{l}\text { Average limit } \\
\text { sensitivity } \\
\text { of assay (pmol) }\end{array}$ & 0.03 & & \\
$\begin{array}{l}\text { Unfed juvenile } \\
\text { pmol/cord }\end{array}$ & $17.3 \pm 1.7$ & $29.0 \pm 2.9$ & $5.4 \pm 0.8$ \\
& $(n=7)$ & $(n=7)$ & $(n=7)$ \\
pmol/ $\mu$ g protein & $1.1 \pm 0.05$ & $1.8 \pm 0.2$ & $0.32 \pm 0.10$ \\
Adult (second- and third-fed) & & \\
pmol/ganglion & $6.1 \pm 1.4$ & $30.5 \pm 2.8$ & $2.9 \pm 0.4$ \\
& $(n=4)$ & $(n=4)$ & $(n=4)$ \\
pmol/cord & $195 \pm 45$ & $976 \pm 90$ & $93 \pm 13$ \\
pmol/ $\mu$ g protein & $0.49 \pm 0.05$ & $3.2 \pm 1.0$ & $0.29 \pm 0.08$
\end{tabular}

The total amount of neurotransmitter detected per nerve cord or ganglion is given with the mean \pm SD. The sample size is indicated in parentheses. Adult values for $\mathrm{pmol} / \mathrm{cord}$ were calculated from $\mathrm{pmol} / \mathrm{ganglion}$ values multiplied by $32 \mathrm{ganglia}$ cord. The values for $\mathrm{pmol} / \mu \mathrm{g}$ of protein (specific content) were obtained by dividing the neurotransmitter content by the protein content determined for each nerve cord or ganglion.

by treatment of Haementeria embryos or juveniles with 5,7-dihydroxytryptamine (Glover and Kramer, 1982; Glover, 1986) no neurons at all are labeled by the antiserum. Moreover, tests carried out in several species using the same or similarly preparcd antiscra as uscd in this report indicate a negligible cross-reactivity with dopamine, noradrenaline, adrenaline, octopamine, GABA, ACh, 5-methoxytryptamine, synephrine, or histamine (Beltz and Kravitz, 1983; Steinbusch et al., 1983; Ono and McCaman, 1984; Taghert and Goodman, 1984). It is possible, however, that the antiserum cross-reacts with 5-HT metabolites, such as tryptophan and 5-hydroxytryptophan.

\section{Dopamine histofluorescence}

To induce the characteristic blue-green fluorescence of dopamine-containing neurons, embryos were dissected to expose the nerve cord and treated with a solution of glyoxylic acid, sucrose, and potassium phosphate for 60-90 sec according to a modification (Stuart, 1981; Stuart et al., 1987) of the method of de la Torre and Surgeon (1976). After removal of the solution, the tissue was daubed dry with a cotton wick, and then dried under a flow of air at room temperature for approximately $1 \mathrm{hr}$. The tissue was then covered with mineral oil, heated in an oven at $95^{\circ} \mathrm{C}$ for $5 \mathrm{~min}$, and mounted between glass coverslips in mineral oil or Fluoromount (Gurr).

The blue-green glyoxylic acid-induced fluorescence of dopamine is very similar to that of other catecholamines, such as dihydroxyphenylalanine (DOPA), norepinephrine, or epinephrine but not octopamine (Lindvall et al., 1974). The evidence that in the leech nervous system such histofluorescence is specific for dopamine, and possibly its precursor DOPA, includes the findings that (1) abdominal ganglia of adult Hirudo medicinalis are capable of synthesizing and accumulating dopamine and octopamine, but not norepinephrine, from tyrosine (Stuart et al., 1974; Sargent, 1977); (2) dopamine, but not norepinephrine, has been detected and measured in these ganglia (McCaman et al., 1973; McAdoo and Coggeshall, 1976); (3) in adult Hirudo, identified neurons homologous to 1 type of neuron described here contain high concentrations of dopamine and DOPA but no detectable norepinephrine or epinephrine (Lent et al., 1983); (4) the nerve cords of adult and juvenile Haementeria contain dopamine (Table 1). It remains possible that a few neurons in segments associated with the subesophageal and caudal ganglia, as well as some of the neurons in the glossophoniid leeches, contain norepinephrine or epinephrine.

\section{GABA uptake}

The capacity of embryonic neurons for high-affinity ${ }^{3} \mathrm{H}-\mathrm{GABA}$ uptake was determined by the autoradiographic method described previously for neurons of adult leeches (Cline, 1983). Embryos were dissected to expose the nerve cord and incubated for $15 \mathrm{~min}$ at $25^{\circ} \mathrm{C}$ in Haementeria 


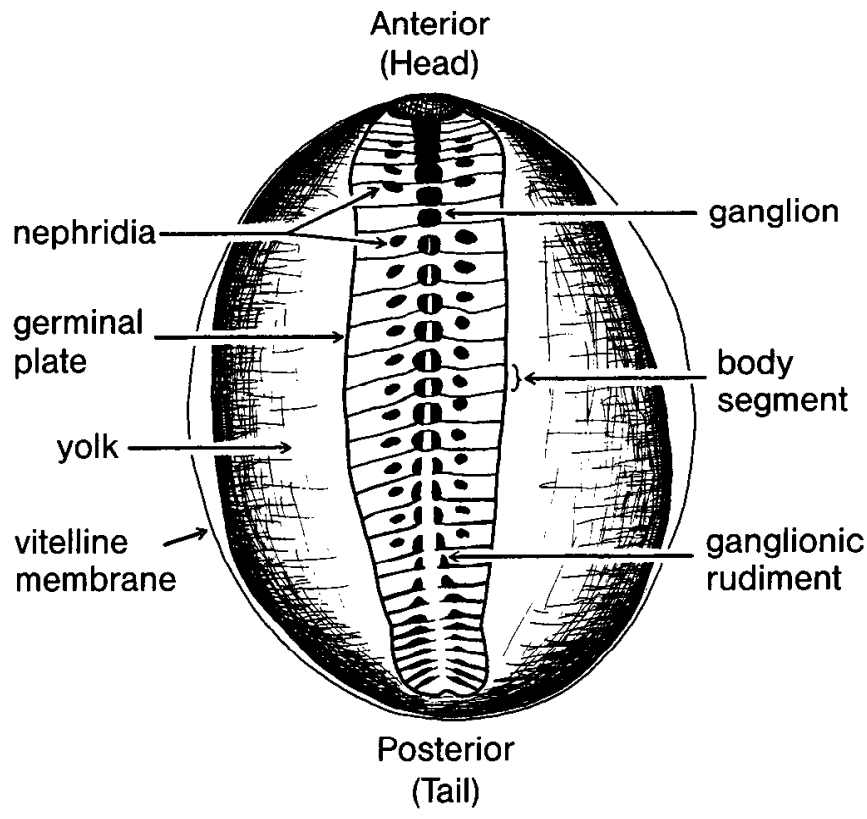

Figure 1. Cartoon of a Haementeria ghilianii embryo, 2-2.5 mm long, and its germinal plate at mid-stage 9 (from Kuwada and Kramer, 1983). Gangliogenesis begins late in stage 8, in the anteriormost segments of the developing germinal plate, and proceeds in a rostrocaudal sequence, so that all 32 segmental ganglia are present by the end of stage 9 . The ganglionic rudiment arises as a sheet of cells lying across the ventral midline. The future borders of the ganglion are delineated by identified muscle cells. The first overt sign of gangliogenesis in a given segment is the appearance of a bilateral pair of thickenings, caused by local proliferation of neural precursor cells and by centripetal migration of other neural precursor cells into the ganglionic rudiment (Torrence and Stuart, 1986). Outgrowth of processes from the neuronal cell bodies begins early in stage 9 , and by late stage 9 , some processes have established the trajectories of the future segmental and connective nerve tracts. By early stage 10 , junction potentials can be recorded from the embryonic muscle fibers, indicating that motor neurons have innervated their peripheral targets, and processes of sensory neurons are seen in the body wall (Kramer and Kuwada, 1983; Kuwada and Kramer, 1983).

Ringer's solution containing 1-10 $\mu \mathrm{M}{ }^{3} \mathrm{H}-\mathrm{GABA}(30 \mathrm{Ci} / \mathrm{mmol}$, New England Nuclear). Following incubation, the embryos were rinsed in Haementeria Ringer's solution, fixed in $2.5 \%$ glutaraldehyde in $0.1 \mathrm{M}$ cacodylate buffer, $\mathrm{pH} 7.4$, for $2 \mathrm{hr}$ at $4^{\circ} \mathrm{C}$, rinsed, dehydrated, and embedded in glycolmethacrylate. The embedded preparations were cut into serial 1-2 $\mu \mathrm{m}$ horizontal sections, mounted on gelatin-coated slides, and dipped in Kodak NTB2 emulsion diluted 1:1 with water. After storage for up to 3 weeks, the slides were developed in Kodak D-19, stained with methylene blue, and examined under a light microscope for the distribution of silver grains in the emulsion. The ganglia were reconstructed from drawings of serial horizontal sections through midbody portions of the nerve cord, and the number and positions of the embryonic neurons that take up GABA were marked on a map of the adult pattern of labeled neurons (Cline, 1983).

\section{Results}

Neurotransmitter content of adult and unfed juvenile tissue

Previous neurochemical studies of the leech were concerned with hirudinid species (Wallace, 1981), whereas the neurochemistry of the embryologically favorable glossiphoniid species had been largely unexplored. Hence, we first surveyed nervous tissue of unfed juvenile and second- and third-fed specimens of the glossiphoniid leech Haementeria to identify the neurotransmitters that are present in amounts detectable by radioenzymatic assays. Whole nerve cords or individual segmental ganglia were dissected from unfed juvenile or second- and third-fed specimens, respectively, and assayed for their content of various neurotransmitters and for the total amount of protein present. The data from the second-fed juvenile and the third-fed adult, being very similar, were pooled, and are referred to as "adult" data in the following. Both adult and unfed juvenile nerve cords were found to contain the neurotransmitters 5-HT, $\mathrm{ACh}$, and dopamine, of which the specific content (relative to total protein) is highest for 5-HT and lowest for dopamine (Table 1).

While the total content of all 3 neurotransmitters is very much greater in the adult than in the unfed juvenile nerve cord, the specific content of $5-\mathrm{HT}$ is about $80 \%$ higher, of ACh about $60 \%$ lower, and of dopamine about the same in the adult as in unfed juvenile nerve cord (Table 1). The radioenzymatic assays also suggested the presence of histamine and octopamine in the nerve cord, at levels near the limit sensitivity of the assay. Some tissues other than the nerve cord, however, definitely contain histamine. For instance, in unfed juvenile specimens we found substantial amounts of histamine in the body wall $(2.8 \mathrm{pmol} /$ segment, $0.07 \mathrm{pmol} / \mu \mathrm{g}$ protein), in the proboscis $(53 \mathrm{pmol} /$ proboscis, $2.8 \mathrm{pmol} / \mu \mathrm{g}$ protein), and in the salivary glands $(>630$ $\mathrm{pmol} / \mathrm{gland},>35 \mathrm{pmol} / \mu \mathrm{g}$ protein). No radioenzymatic assay was available to determine the GABA content of the nerve cord. However, previous work had indicated the presence of GABA as a neurotransmitter in the Haementeria nervous system (Cline, 1983, 1986).

In the studies to be reported here, we ascertained the time course of the differentiation of ACh, 5-HT, dopamine, and GABA metabolism.

\section{Embryonic stages of development}

The embryonic development of glossiphoniid leeches has been divided into 11 stages, beginning with egg deposition and culminating in the juvenile leech (Fernandez, 1980; Weisblat et al., 1980; Stent et al., 1982). During the first 8 stages, the uncleaved, yolk-filled egg is transformed via a series of well-defined cell divisions and movements into a narrow germinal plate, which lies over the yolk along the future ventral midline of the embryo (Fig. 1). The nervous system, skin, muscles, and other ectodermal and mesodermal organs of the leech arise from this plate. During stages 9 and 10, the germinal plate elongates and expands around the circumference of the embryo, until its leading margins meet on the dorsal midline and fuse, thus closing the leech body. The completion of body closure marks the end of stage 10.

Development of the germinal plate proceeds according to a rostrocaudal gradient, with the front end of the plate being about 2-3 d more advanced than the hind end. The final stages of morphological development occur during stage 11 , the end of which is marked by exhaustion of the yolk in the gut. A small leech is now present, which is capable of feeding and is referred to as an unfed juvenile until its first feeding.

Stages 9-11 have been divided into substages, each substage corresponding to about $1 \mathrm{~d}$ of development of IIaementeria at $27^{\circ} \mathrm{C}$. These stages are, respectively, about 4,5 , and $20 \mathrm{~d}$ in duration. Substages are designated by the stage number, followed in parentheses by the ratio of the number of days elapsed from the beginning of the stage to the total number of days in the stage. Thus, at stage 9(1/4) an embryo has completed about a day of development after reaching stage 9 (Kuwada and Kramer, 1983). For each of the substages of stages 9 and 10, and for the first half of the substages of stage 11, there exist (as yet 

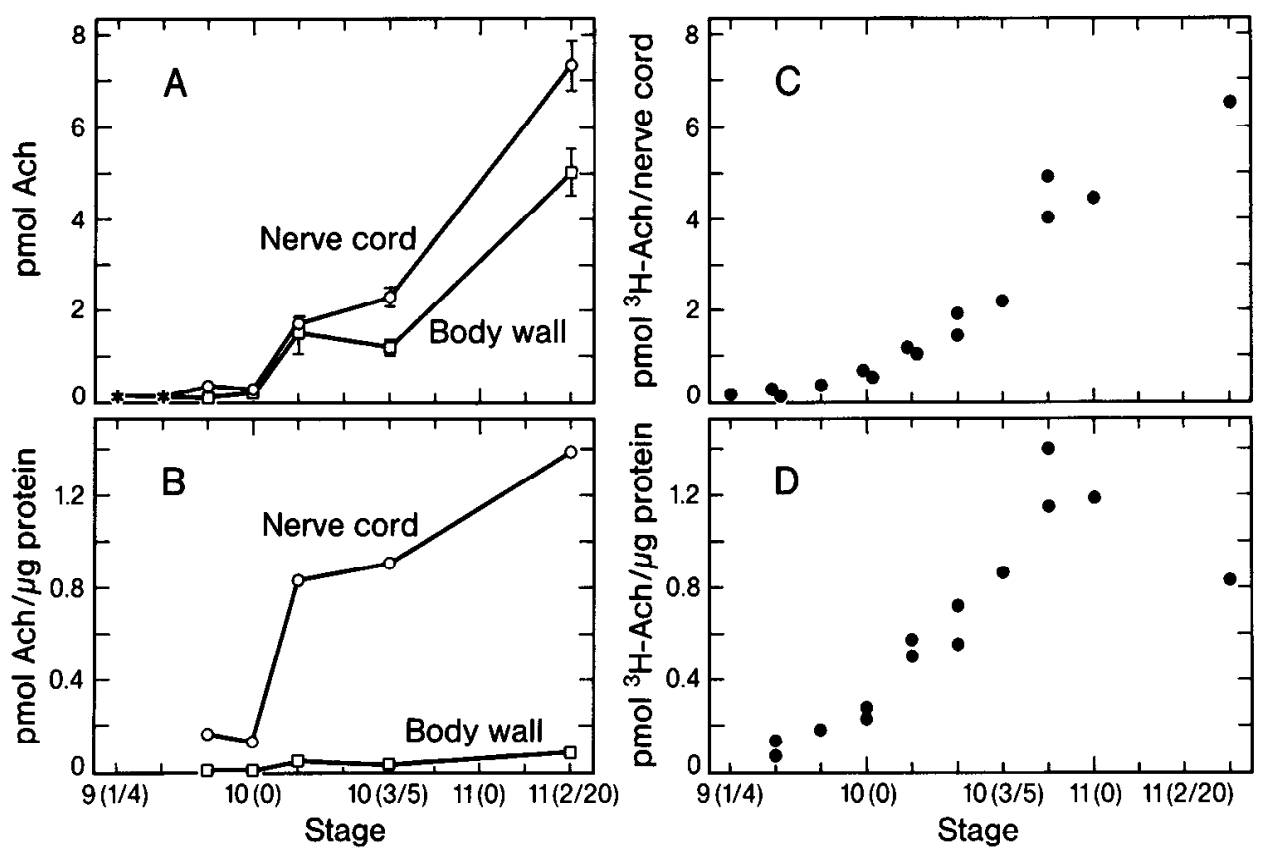

Figure 2. Development of ACh metabolism. A, ACh content of nerve cord and body wall. Asterisks indicate values obtained from dissected germinal plates (nerve cord plus body wall). Each point represents the mean of 3 sets of duplicate determinations. Error bars indicate SD. The absence of an error bar means that the SD is less than the height of the symbol. However, the SDs do not take into account that some of the ACh contents were obtained from different cohorts of embryos, which is likely to introduce some additional scatter into the data. Average limit sensitivity of assay: 0.03 pmol. $B$, Specific ACh content per microgram protein of nerve cord and body wall. The points were obtained by dividing each point in $A$ by the protein content of the corresponding tissue and stage, as shown in Figure 3. (Data from the dissected germinal plate are not included.) $C$, Capacity for synthesis and accumulation of $\mathrm{ACh}$ by the nerve cord. Each point represents a single determination following a $3 \mathrm{hr}$ incubation in ${ }^{3}$ H-choline. $D$, Specific capacity for synthesis and accumulation of ACh by the nerve cord per microgram protein. The points were obtained by dividing each point in $C$ by the protein content of the corresponding stage (Fig. 3).

unpublished) diagnostic morphological criteria. Only normal embryos that met these criteria were included in this study.

\section{Neurotransmitter content of embryonic tissues}

To determine the neurotransmitter content of the embryonic tissues, the germinal plate was separated from the yolk and provisional integument at various developmental stages. In the case of embryos at, or older than, stage $9(2 / 4)$, the nerve cord was dissected from the germinal plate. Both nerve cord and the remainder of the plate (referred to as body wall) were then subjected separately to radioenzymatic assay. In the case of embryos younger than stage $9(2 / 4)$, where a complete dissection is not feasible, the neurotransmitter content of the entire germinal plate was assayed.

\section{Acetylcholine}

The results of the ACh assays are presented in Figure $2 A$. At stages $9(1 / 4)$ and $9(2 / 4)$ the germinal plate, with its nascent ganglia, contains a low, but significant, amount of $\mathrm{ACh}$. Between stages $9(2 / 4)$ and $10(0)$ the $A C h$ content of the nerve cord and body wall increases moderately. After stage $10(0)$, the ACh content rises rapidly in both tissues, so that by stage $11(2 / 20)$ it has increased 60 -fold in the nerve cord and 40-fold in the body wall over the original amounts. Moreover, as seen in Table 1, by the end of stage 11 the $\mathrm{ACh}$ content of the unfed juvenile nerve cord has risen to twice that present at stage $11(2 / 20)$.

To ascertain the degree to which the increase in $\mathrm{ACh}$ content of the embryonic tissues reflects a process of specific neurochemical differentiation rather than a nonspecific consequence of general growth, we determined the total protein content of equivalent nerve cord and body wall preparations. These anal- yses show that the total protein contents of nerve cord and body wall rise slowly during stages 9 and 10 and then more rapidly during stage 11 , resulting in approximately 10 - and 30 -fold increases, respectively (Fig. 3).

The specific content (relative to total protein) of $\mathrm{ACh}$ in nerve cord and body wall is plotted in Figure $2 B$. The specific content of $\mathrm{ACh}$ in the nerve cord rises more than 6-fold between stages $9(3 / 4)$ and $11(2 / 20)$, indicating that the developmental increase in absolute ACh content is attributable to specific cell differentiation rather than to the general growth of nervous tissue.

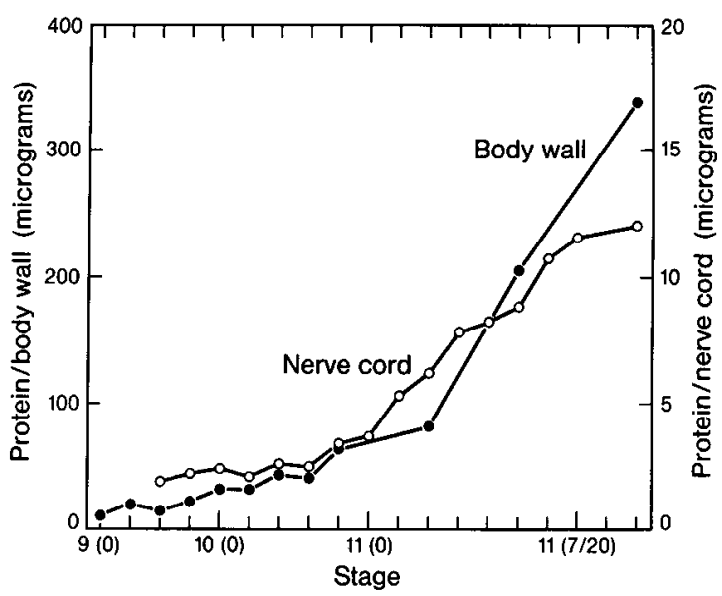

Figure 3. Development of total protein of the nerve cord (open circles) and body wall (closed circles). Each point represents the average of 15 measurements, with the fewer measurements having been made during stage 11 . 

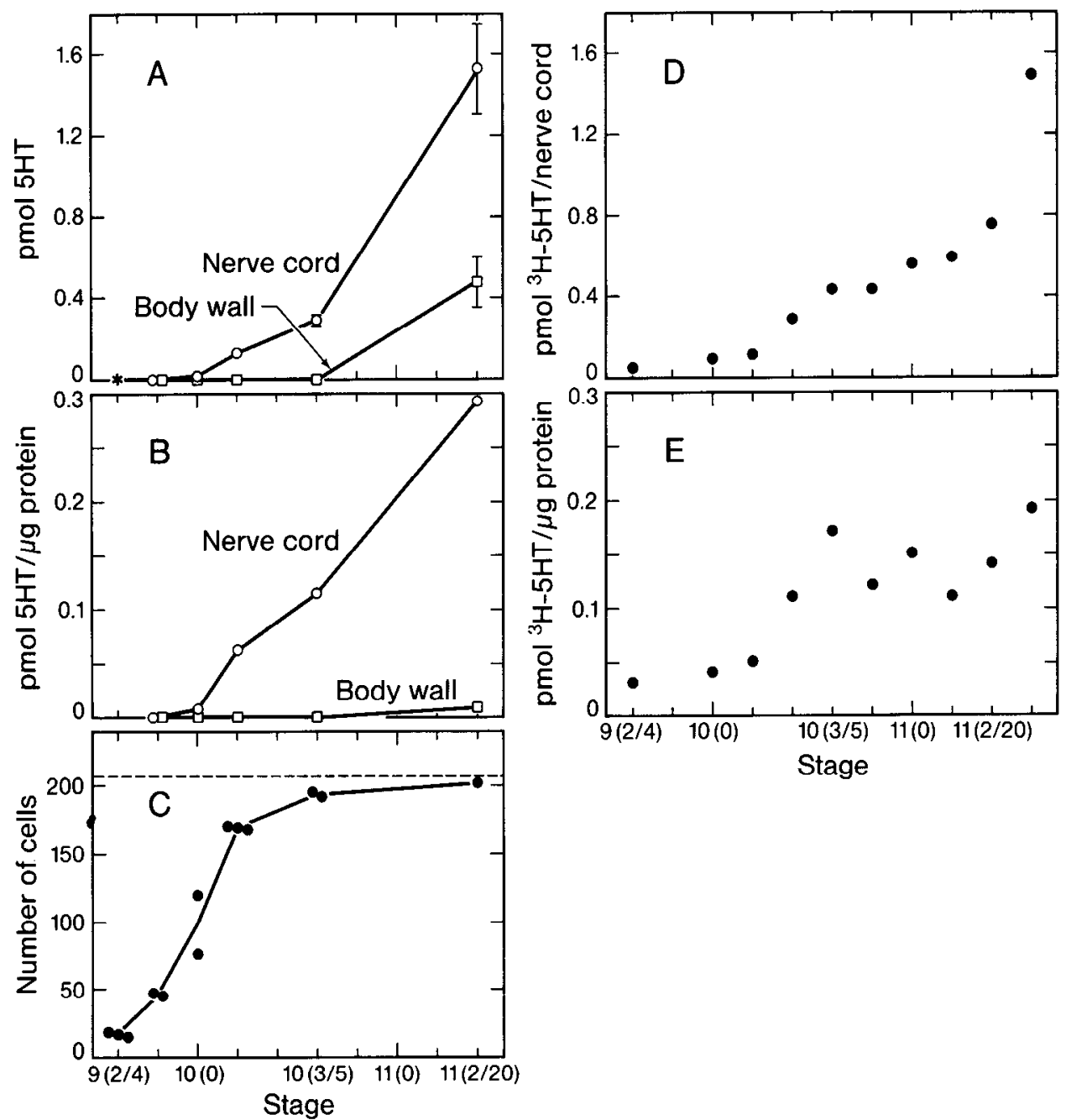

Figure 4. Development of 5-HT metabolism. A, The 5-HT content of nerve cord and body wall. Asterisk indicates the value for a germinal plate (nerve cord plus body wall). Each point represents the mean of 3 sets of duplicate determinations, except for the stage $10(0)$ nerve cord, which is a single determination. Error bars indicate SD. The absence of an error bar means that the SD is less than the height of the symbol. The 5-HT contents were obtained from different cohorts of embryos, which is likely to introduce some additional scatter into the data. Average limit sensitivity of assay: $0.06 \mathrm{pmol}$. Assay values obtained earlier than stage $10(0)$ nerve cord and stage 11(2/20) body wall are below the limit sensitivity (the stage $9(2 / 4)$ and stage $9(3 / 4)$ nerve cords therefore contain $<0.1$ pmol and $<0.7$ pmol, respectively). $B$, Specific 5 -HT content per microgram protein of nerve cord and body wall. The points were obtained by dividing each point in $A$ by the protein content of the corresponding tissue and stage, as shown in Figure 3. (The datum from the germinal plate is not included.) $C$, Number of 5-HT-immunoreactive neurons in the nerve cord. Each point represents the number of stained neurons in a single preparation, obtained from the same cohorts as those subjected to radioenzymatic assays. The dashed horizontal line represents the adult complement of 5-HT-containing neurons. $D$, Total capacity for synthesis and accumulation of 5-HT by the nerve cord. Each point represents a single determination following a $3 \mathrm{hr}$ incubation in ${ }^{3} \mathrm{H}-5$-hydroxytryptophan. $E$, Specific capacity for synthesis and accumulation of 5-HT by the nerve cord per microgram protein. The points were obtained by dividing each point in $D$ by the protein content of the corresponding stage (Fig. 3).

Concurrently, the (very much lower) specific ACh content of the body wall rises by only a factor of about 1.5 , suggesting that the developmental increase in the amount of body wall $\mathrm{ACh}$ is due to a proliferation of cholinergic axons and terminals, which keeps pace with the general growth of the body wall tissues. Comparison of the data from embryos, unfed juveniles, and adult leeches (Fig. 2B, Table 1) shows that the specific ACh content of the nerve cord reaches a maximum in the first half of stage 11 and then declines again, having fallen in the adult to a value less than $40 \%$ of maximum.

\section{Serotonin}

The results of the 5-HT assay are presented in Figure 4A. In the nerve cord, the radioenzymatic assay first detects the presence of 5-HT at stage 10(0), after which the 5-HT content increases rapidly, until by stage $11(2 / 10)$ a 75 -fold increase over the initially detectable amount has been reached. During the remainder of stage 11 , there is a further 20 -fold increase in 5 -HT content (Table 1). Thus, ACh and 5-HT levels in the embryonic nerve cord show quite similar kinetics of appearance.

In the body wall, $5-\mathrm{HT}$ is not detectable at stage $10(3 / 5)$ but is definitely present by stage $11(2 / 20)$. Thus, 5 -HT becomes detectable in the embryonic body wall significantly later than does ACh.

The specific content of 5-HT in nerve cord and body wall is plotted in Figure $4 B$. The specific 5-HT content of the nerve cord rises more than 7-fold between stages $10(0)$ and $11(2 / 10)$, and by another factor of 6 during the remainder of stage 11 
(Table 1), indicating that this increase, just as in the case of $\mathrm{ACh}$, is attributable to specific cell differentiation rather than to the general growth of nervous tissue. However, in contrast to the eventual decline of the specific ACh content, the specific 5-HT content of the nerve cord continues to rise into adulthood, at which stage its level has risen 10 -fold over that present during the first half of stage 11 .

The course of appearance of 5-HT in the embryonic nerve cord was also followed by means of an immunocytochemical assay, using an anti-5-HT antibody. This assay permits the identification of individual neurons that contain 5-HT (and/or possibly its metabolites) in embryos. A full description of the results of these experiments will be published elsewhere (D. K. Stuart and J. C. Glover, unpublished observations). Here, we present only the total number of neurons in the nerve cord at various stages of development that react with anti-5-HT antibody (Fig. $4 C)$. The first such neurons appear by stage $9(2 / 4)$, or $2 \mathrm{~d}$ before any 5 -HT is detected by the radioenzymatic assay (Fig. $4 A$ ). Thereafter, their number nearly doubles on each succeeding day up to stage $10(1 / 5)$; after this, their number increases more slowly, until the adult complement of 5-HT-containing neurons has been nearly reached by stage $11(2 / 20)$. Thus, the increase in 5-HT content of the nerve cord before stage $10(3 / 5)$ (Fig. $4 A$ ) is attributable in part to an increase in the number of neurons containing 5-HT. After stage $10(3 / 5)$, when $94 \%$ of the adult 5-HT-containing neurons are visualized by immunocytochemistry but only a small fraction of the 5-HT content of the unfed juvenile nerve cord is as yet present, the further rise in the total 5-HT must be attributable to increases in the amount of 5-HT per neuron. These increases in the 5-HT content of individual neurons reflect their spatial growth (size of the cell body and arborization), as well as their increased concentration of intracellular 5-HT manifest in the marked rise in intensity of the immunocytochemical staining of individual neurons during development.

\section{Dopamine}

The radioenzymatic assay is not sufficiently sensitive for reliable detection of dopamine in embryonic tissues at stage $10(3 / 5)$ or earlier, when the dopamine content is less than 0.02 pmol per nerve cord. However, by stage $11(2 / 20), 0.25 \pm 0.02 \mathrm{pmol}$ of dopamine per nerve cord is present, corresponding to a specific content of $0.05 \mathrm{pmol} / \mu \mathrm{g}$ protein. During the remainder of stage 11 , a further 20 -fold increase in total, and a 6 -fold increase in specific, dopamine content occurs (Table 1), just as for 5-HT.

The course of appearance of dopamine (and/or possibly DOPA) in the embryonic nerve cord was also followed by observing the blue-green histofluorescence induced specifically in dopaminecontaining neurons by glyoxylic acid. The cell bodies of the few paired dopamine-containing neurons present in each segment lie outside the ventral nerve cord in the segmental body wall. These neurons project their axons into the ventral nerve cord, where they arborize profusely. Glyoxylic acid treatment of embryos dissected at various stages revealed that dopamine-specific histofluorescence (Stuart, 1981; Blair, 1983; Lent et al., 1983; Stuart et al., 1987) is first inducible in the nervous system at stage 10(0); at this time, in the anteriormost segments, the peripheral cell body of the dopamine-containing neuron designated as MD and its centripetally projected processes fluoresce (Fig. 5). With subsequent development, the dopamine-containing centripetal processes of neuron MD grow in length and undergo their typical profuse arborization (Fig. 5), until they

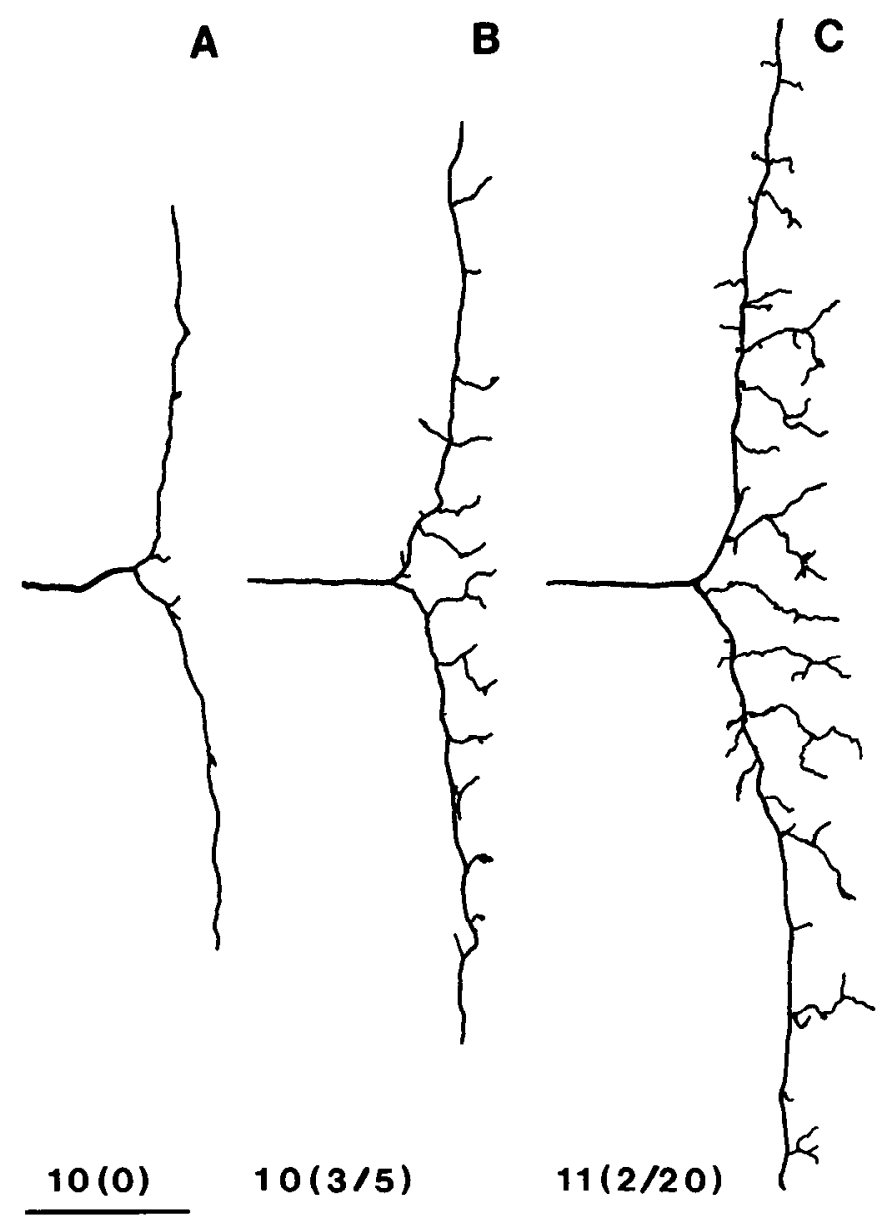

Figure 5. Development of the central arborization of the dopaminecontaining neuron MD. The tracings of the fluorescent arborization of an MD neuron in a midbody segmental ganglion were drawn from photomicrographs. Anterior is uppermost, and the neuronal arborizations are drawn as seen in the neuropil of the left hemiganglion. Dopamine histofluorescence was induced by glyoxylic acid treatment. $A$, Stage 10(0) embryo. $B$, Stage $10(3 / 5)$ embryo. $C$, Stage $11(2 / 20)$ embryo. Scale bar, $25 \mu \mathrm{m}$.

densely fill the ganglionic neuropil in the unfed juvenile (Fig. 6). Data not presented here show that the general rostrocaudal developmental gradient is manifest during this period by the more extensive arborization of the MD neuron in more anterior ganglia. A second pair of peripheral dopamine-containing neurons, designated $\mathrm{LD} 1$, is not visualizable by induced fluorescence until the beginning of stage 11 .

\section{Neurotransmitter synthesis and accumulation}

Another approach to the study of the development of neurochemical differentiation is to examine the capacity of the embryonic nervous system to synthesize and accumulate neurotransmitters. For this purpose, the nerve cord (or, in the case of early embryos, the germinal plate) is removed from embryos and incubated in the presence of a radioactively labeled precursor of a particular type of neurotransmitter. After incubation, the labeled neurotransmitter synthesized is extracted from the nervous tissue, separated from precursor molecules and other labeled reaction products, and measured for amount of radioactive label. From these data and the known specific radioactivity of the labeled precursor and duration of the incubation, 


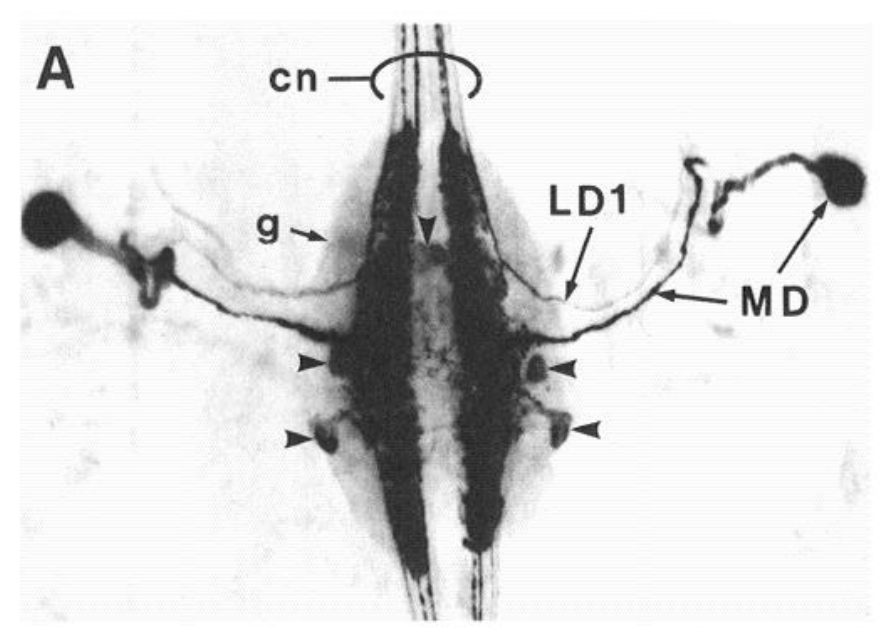

B

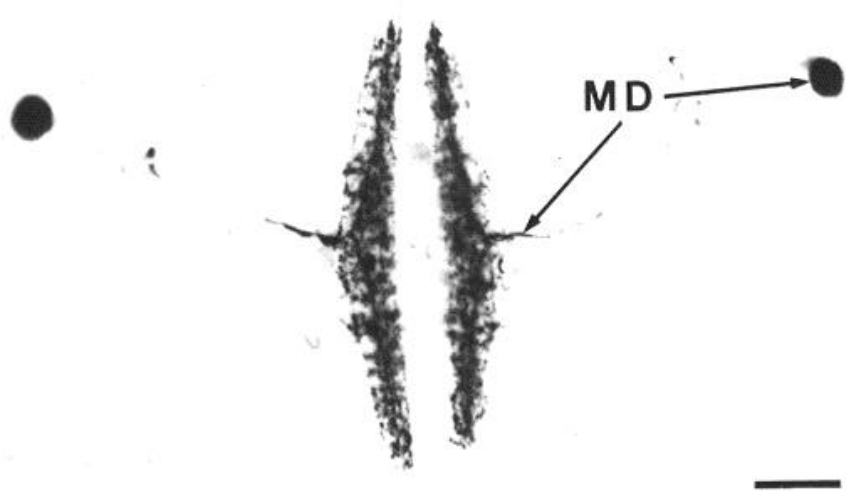

Figure 6. Photomicrograph of the peripheral cell body of the paired, dopamine neuron MD and of its projection into abdominal ganglion 3 $(g)$ of an unfed juvenile leech, visualized as a negative image of the bluegreen monoamine histofluorescence induced by glyoxylic acid. Anterior is uppermost. $A$ and $B$ present the same field of view, with $B$ having been printed more lightly than $A$ to reveal the extensive branching of dopamine-containing processes in the central neuropil (cf. Fig. 5). The axon and central arborization of another paired dopamine neuron, LD1, are also visible, but its peripheral cell body lies outside the field of view. Within the nerve cord the MD neuron sends major axon branches into both the anterior and posterior connective neurons $(\mathrm{cn})$. The LD1 neuron sends 1 major axon branch into the anterior connective nerve. The yellow, glyoxylic acid-induced 5-HT histofluorescence reveals the cell bodies of 5-HT neurons within the ganglion (arrowheads). Scale bar, 50 $\mu \mathrm{m}$.

the capacity of the nerve cord to synthesize and accumulate neurotransmitter can then be estimated (Hildebrand et al., 1971; Sargent, 1977).

\section{Acetylcholine}

We assayed the amounts of ${ }^{3} \mathrm{H}$-ACh accumulated by embryonic nerve cords incubated in the presence of the ACh precursor ${ }^{3} \mathrm{H}$ choline. As early as the last day of stage 8, i.e., prior to formation of any complete segmental ganglia, the as yet incompletely fused germinal plate accumulates the significant amount of about 0.01 pmol ${ }^{3} \mathrm{H}$-ACh during a $3 \mathrm{hr}$ incubation period. As shown in Figure $2 \mathrm{C}$, the capacity for ${ }^{3} \mathrm{H}-\mathrm{ACh}$ synthesis and accumulation has risen about 10 -fold by stage $9(1 / 4)$, and it increases with further development at about the same rate as the total ACh content (Fig. $2 A$ ). In fact, at each stage examined, the capacity

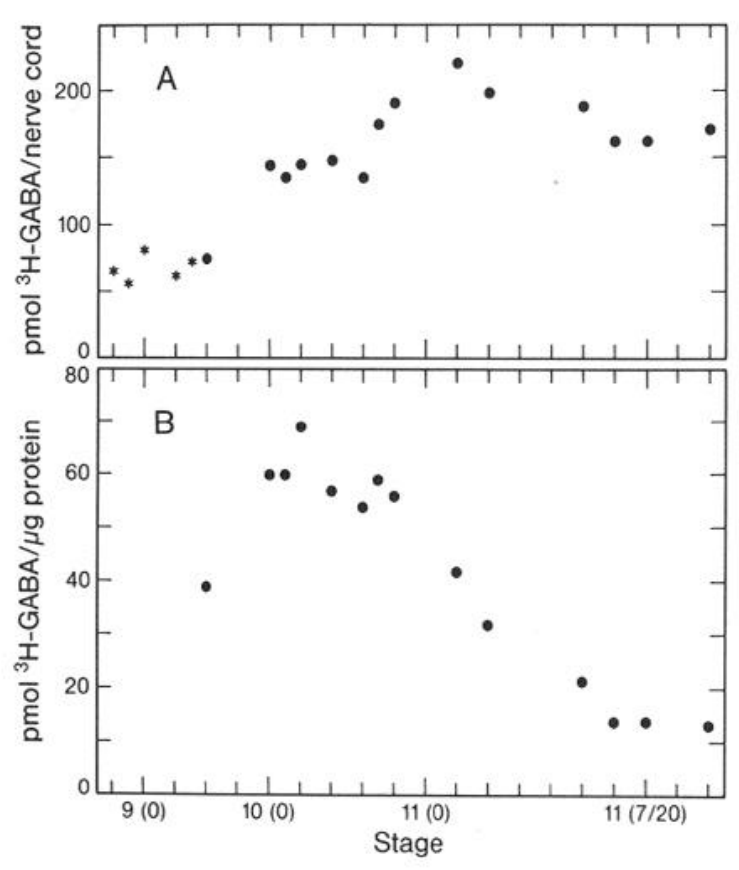

Figure 7. Development of GABA metabolism. A, Capacity for synthesis and accumulation of GABA by the nerve cord. Each point represents the mean of 4 determinations following $3 \mathrm{hr}$ incubations in ${ }^{3} \mathrm{H}$ glutamic acid. Asterisks indicate values obtained from germinal plates (nerve cord plus body wall). $B$, Specific capacity for synthesis and accumulation of GABA by the nerve cord per microgram protein. The points were obtained by dividing each value in $A$ by the protein content of the corresponding stage provided by Figure 3. (In 2 cases, the total protein content for the corresponding stage was estimated by interpolation of the values determined for the immediately preceding and following stages.) Data from the dissected germinal plate are not included.

of the nerve cord to synthesize and accumulate $\mathrm{ACh}$ from ${ }^{3} \mathrm{H}$ choline during a $3 \mathrm{hr}$ incubation is roughly equal to the total amount of ACh present (Fig. $2 A$ ). This result indicates that the $3 \mathrm{hr}$ incubation of the nerve cord in the reaction mixture is sufficient to turn over its intracellular ACh pool at least once. Figure $2 D$ shows the specific capacity for synthesis and accumulation of ACh relative to the total protein content of the nerve cord at various stages. Just as for the specific content of $\mathrm{ACh}$ in the nerve cord, the specific synthetic capacity for ACh rises more than 6-fold during development, indicative of the ongoing differentiation and maturation of $\mathrm{ACh}$ metabolism in cholinergic neurons. This rise is presumably attributable, at least in part, to a progressive increase in the specific content of CAT (Sargent, 1977), the enzyme that catalyzes the conversion of choline to ACh.

We assayed the amounts of $\mathrm{ACh}$ accumulated by 4 single and 4 pairs of ganglia, dissected from 2 second-fed juvenile specimens. We also measured the total amount of protein in the nerve cord of a third, equivalently sized, second-fed specimen. These measurements showed a capacity to synthesize and accumulate ${ }^{3} \mathrm{H}-\mathrm{ACh}$ in $3 \mathrm{hr}$ of $144 \pm 48 \mathrm{pmol} /$ nerve cord (consisting of 32 ganglia), corresponding to a more than 20 -fold increase over that of the nerve cords of stage 11(3/20) embryos (compare Fig. 2C). However, relative to total protein content, the specific capacity of the nerve cords of these second-fed specimens to synthesize and accumulate ${ }^{3} \mathrm{H}-\mathrm{ACh}$ in $3 \mathrm{hr}$ is only $0.50 \pm 17 \mathrm{pmol} / \mu \mathrm{g}$ protein, indicative of a relative decline from the early stage 11 level (compare Fig. $2 D$ ) similar to that ob- 
served for the specific ACh content (compare Table 1). Nevertheless, in the second-fed, as in the embryonic nerve cord, the specific capacity for synthesis and accumulation of ${ }^{3} \mathrm{H}-\mathrm{ACh}$ is roughly equal to the specific ACh content, indicating that in the second-fed juvenile the $3 \mathrm{hr}$ incubation time also suffices to allow at least one turnover of the ACh pool.

\section{Serotonin}

The amounts of ${ }^{3} \mathrm{H}-5$-HT synthesized and accumulated by embryonic nerve cords incubated in the presence of the 5-HT precursor ${ }^{3} \mathrm{H}$-5-hydroxytryptophan are presented in Figure $4 D$. The capacity for this synthetic activity is clearly present in the stage $9(2 / 4)$ nerve cord, at the time when the immunocytochemical test reveals 5-HT-immunoreactive cell bodies (Fig. 4C). Upon further development, the capacity for synthesis and accumulation of 5-HT rises at about the same rate as the total $5-\mathrm{HT}$ content, such that at each stage examined, the amount of ${ }^{3} \mathrm{H}-$ 5-HT accumulated during a $3 \mathrm{hr}$ incubation period is roughly equal to the total amount of 5-HT present (Fig. 4A). This indicates that, as is the case for the ACh pool, the $3 \mathrm{hr}$ incubation period of the nerve cord is sufficient to allow at least one turnover of the 5-HT pool. Figure $4 E$ shows the specific capacity for synthesis and accumulation of 5-HT relative to the total protein content of the nerve cord at various stages. The more than 6-fold rise of that specific capacity is probably attributable, at least in part, to a progressive increase in the specific content of aromatic-amino acid-decarboxylase, the enzyme that catalyzes the conversion of 5-hydroxytryptophan to 5-HT in leech neurons (Coggeshall et al., 1972).

\section{$G A B A$}

Although it proved difficult to assay the total GABA content of the embryonic leech nervous system, the capacity of the nerve cord to synthesize ${ }^{3} \mathrm{H}$-GABA from ${ }^{3} \mathrm{H}$-glutamic acid could be determined (Fig. 7A). However, the amount of ${ }^{3} \mathrm{H}-\mathrm{GAB} \Lambda$ accumulated intracellularly during the $3 \mathrm{hr}$ incubation period was so low that the labeled neurotransmitter released into the incubation mixture was also included in the measurement. The low level of intracellular accumulation of newly synthesized GABA may be attributable to the reported tonic release of neurotransmitter by GABAergic neurons, both for the inhibitory motor neurons of the leech (Cline, 1983, 1986; Granzow et al., 1985 ) and in the vertebrate nervous system (Tapia, 1983).

These assays showed that as early as the last day of stage 8 there exists a significant capacity for GABA synthesis. The level of this synthetic capacity remains roughly constant until stage $9(2 / 4)$. Thereafter, the capacity for GABA synthesis rises continuously, until by stage $10(4 / 5)$ it has reached a level about 3 times that present initially. Figure $7 B$ shows the specific capacity for synthesis and accumulation of GABA relative to the total protein content of the nerve cord at various stages. In contrast to the appreciable rise of the specific synthetic capacities for $\mathrm{ACh}$ and 5-HT between midstage 9 and early stage 11 , the specific capacity for GABA synthesis remains more or less constant during stage 10 and then falls to about a third of the earlier level during stage 11 .

\section{GABA uptake}

The adult leech nerve cord is not only capable of synthesizing GABA from glutamate, but it can also take up GABA selectively from the extracellular fluid. Neurons possessing this selective
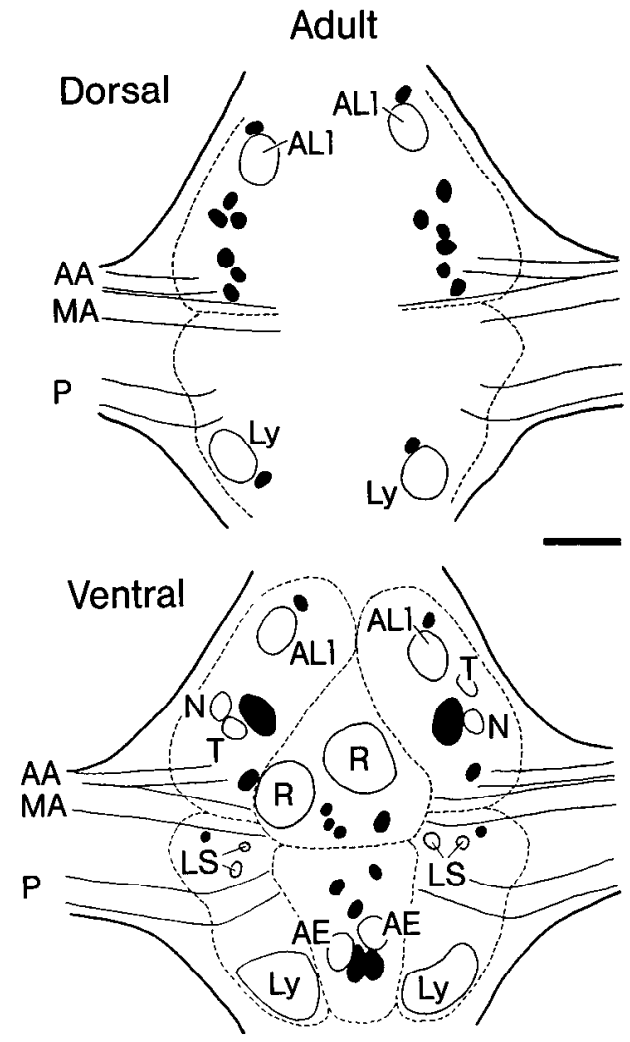

Figure 8. Summary diagram of the relative positions of neuronal cell bodies taking up GABA in adult Haementeria ganglia. Labeled cell bodies are solid black and identified landmark cells are unshaded. The labeled neurons were identified in autoradiographs of serial sections through adult ganglia. Cell packets are outlined in dashed lines, and the segmental nerve roots are designated as $A A, M A$, and $P$. The dorsal aspect of the ganglion is shown above the ventral aspect; anteriormost is up. The positions and sizes of the labeled neuronal cell bodies were drawn onto an outline of the adult Haementeria ganglion (Kramer and Goldman, 1981). [This figure is based on data from Cline (1983).] The landmark neurons are the large anterior lateral $1(A L I)$, the Leydig $(L Y)$, the mechanosensory ( $T$ and $N$ ), the giant Retzius $(R)$, the lateral serotonin $(L S)$, and the annulus erector motor $(A E)$ neurons. Scale bar, 100 $\mu \mathrm{m}$.

GABA uptake system can be identified autoradiographically after exposure of the nerve cord to ${ }^{3} \mathrm{H}-\mathrm{GABA}$ and constitute a specific set of about 30 neurons in segmental ganglia of the adult (second- and third-fed) Haementeria nerve cord (Cline, 1983) (Fig. 8). To determine the course of development of this uptake system, embryos were dissected to expose their nerve cord, incubated in the presence of $1-10 \mu \mathrm{M}{ }^{3} \mathrm{H}-\mathrm{GABA}$, and then fixed, sectioned, and prepared for autoradiography. Cells capable of GABA uptake can be visualized by stage $9(1 / 4)$, at which time a single pair of cell bodies on the posteromedial ventral aspect of each of the anterior segmental ganglia takes up GABA. By stage $9(3 / 4)$ each of the anterior ganglia of the nerve cord may contain as many as 7 additional cell bodies that take up GABA (Fig. 9). The serial sections did not reveal any ${ }^{3} \mathrm{H}$-GABA-labeled processes or neurites from these cells (Fig. 10). Since at later developmental stages ${ }^{3} \mathrm{H}$-GABA-labeled neurites were detected from these cclls, it is likely that at stage $9(3 / 4)$ these neurons have not yet initiated neurite outgrowth.

The general rostrocaudal developmental gradient of the germinal plate is apparent also in the maturation of the GABA 
$9(3 / 4)$
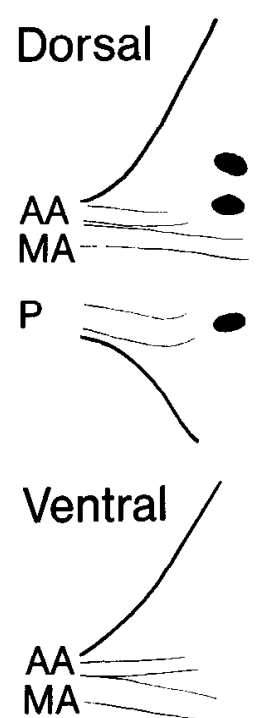

Figure 9. Summary diagram of the relative positions of the neuronal cell bodies taking up GABA at various stages of development. The outline of the ganglion and the symbols for the segmental nerve roots and the identified landmark cells are the same as in Figure 8. The labeled neurons were identified in autoradiographs of serial sections through embryonic ganglia. Not all of the neurons marked in black are necessarily found to take up GABA in every ganglion observed, but neurons for which uptake was found in only 1 ganglion are marked by an asterisk. Thus, the summary maps, being compilations of the labeling patterns in several ganglia, may show more labeled neurons marked than were seen in any 1 ganglion. The number of ganglia examined at each stage was as follows: stage $9(3 / 4), n=8$; stage $10(1 /$ 5), $n=6$; stage $10(2 / 5), n=1$; stage $11(0), n=3$. We expect that as development proceeds the number of neurons taking up GABA will increase or remain the same. However, the number of neurons shown here to take up GABA at stage $10(1 / 5)$ is slightly greater than that at stage $10(2 /$ 5). This discrepancy may be due to a direct correlation between GABA uptake by a neuron and the rate of its electrical activity just prior to its exposure to ${ }^{3} \mathrm{H}-\mathrm{GABA}$, as observed in adult leech neurons (Cline et al., 1985). For instance, the data shown for stage $10(1 / 5)$ were compiled from 6 ganglia from 1 specimen. This embryo may have happened to have a much higher level of electrical activity than the stage $10(2 / 5)$ embryos that were analyzed.
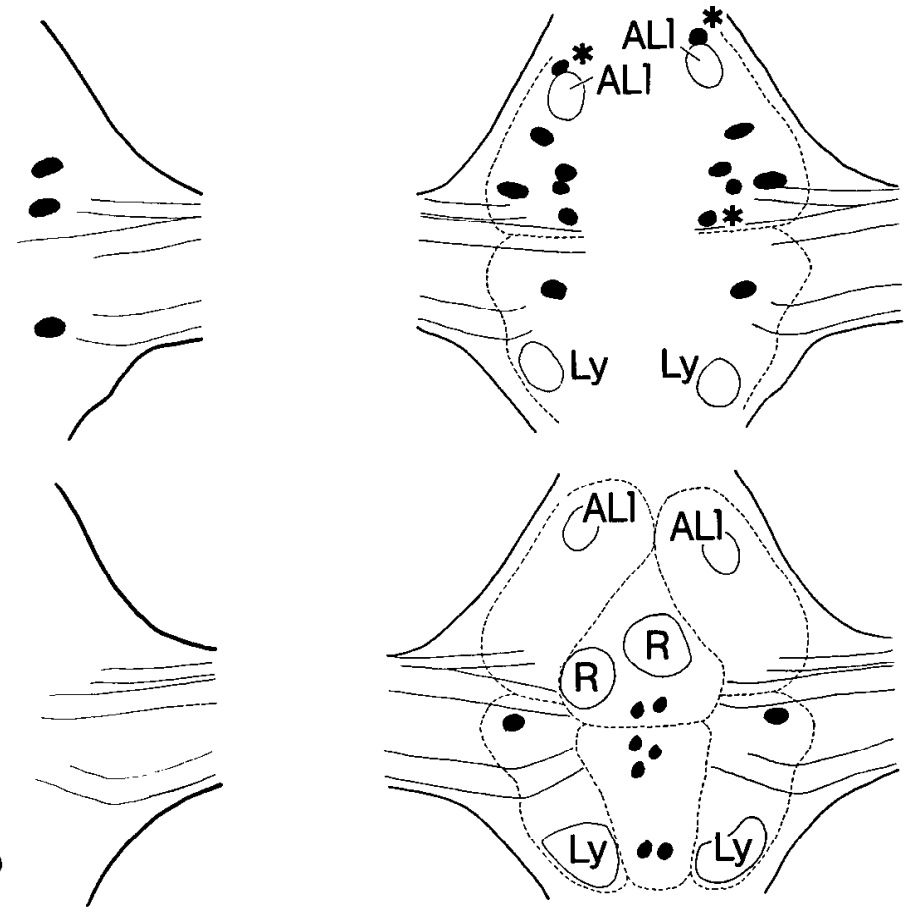

$11(0)$
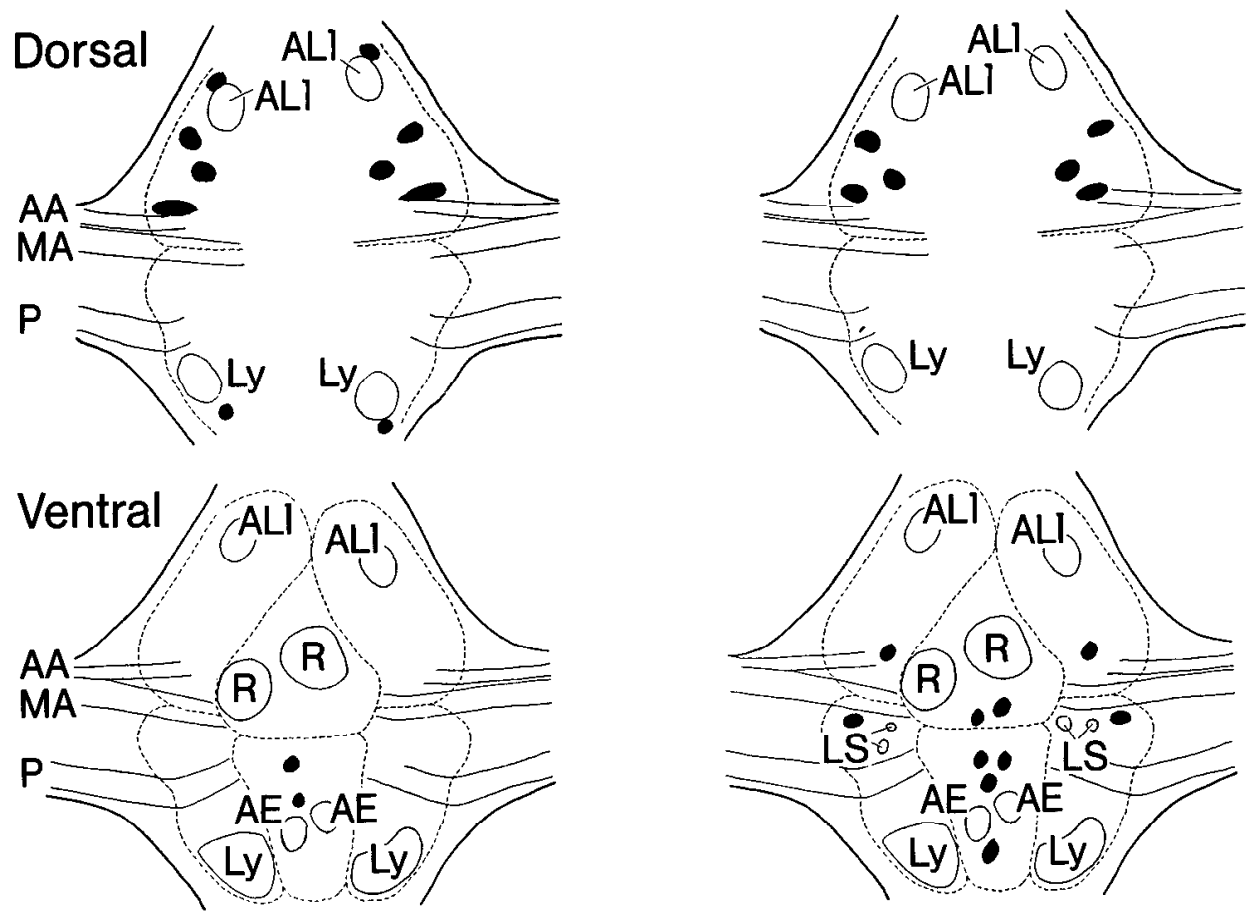

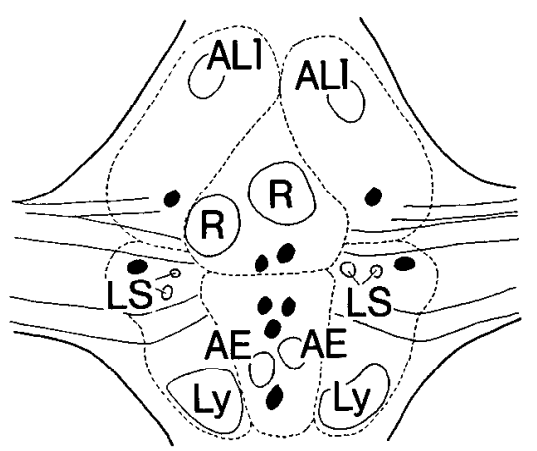

uptake system. Figure 11 shows the distribution of cells taking up GABA in abdominal ganglia 11-18 in a stage 9(3/4) embryo. The posteromedial ventral cell pair takes up GABA in all abdominal ganglia 11-18 at stage 9(3/4). But of the 2 pairs of anterolateral neurons on the dorsal aspect that take up GABA in ganglion 11, only the anterior pair takes up GABA in ganglia
12-16, and neither takes up GABA in ganglia 17-18. At later stages, both of these cell pairs take up GABA in all ganglia 1118. Thus, the appearance of the GABA uptake system proceeds in a sequential order: first in the posteromedial ventral cell pair, next in the posterior, and then in the anterior of the 2 anterolateral dorsal cell pairs. During stage 10, the GABA uptake 

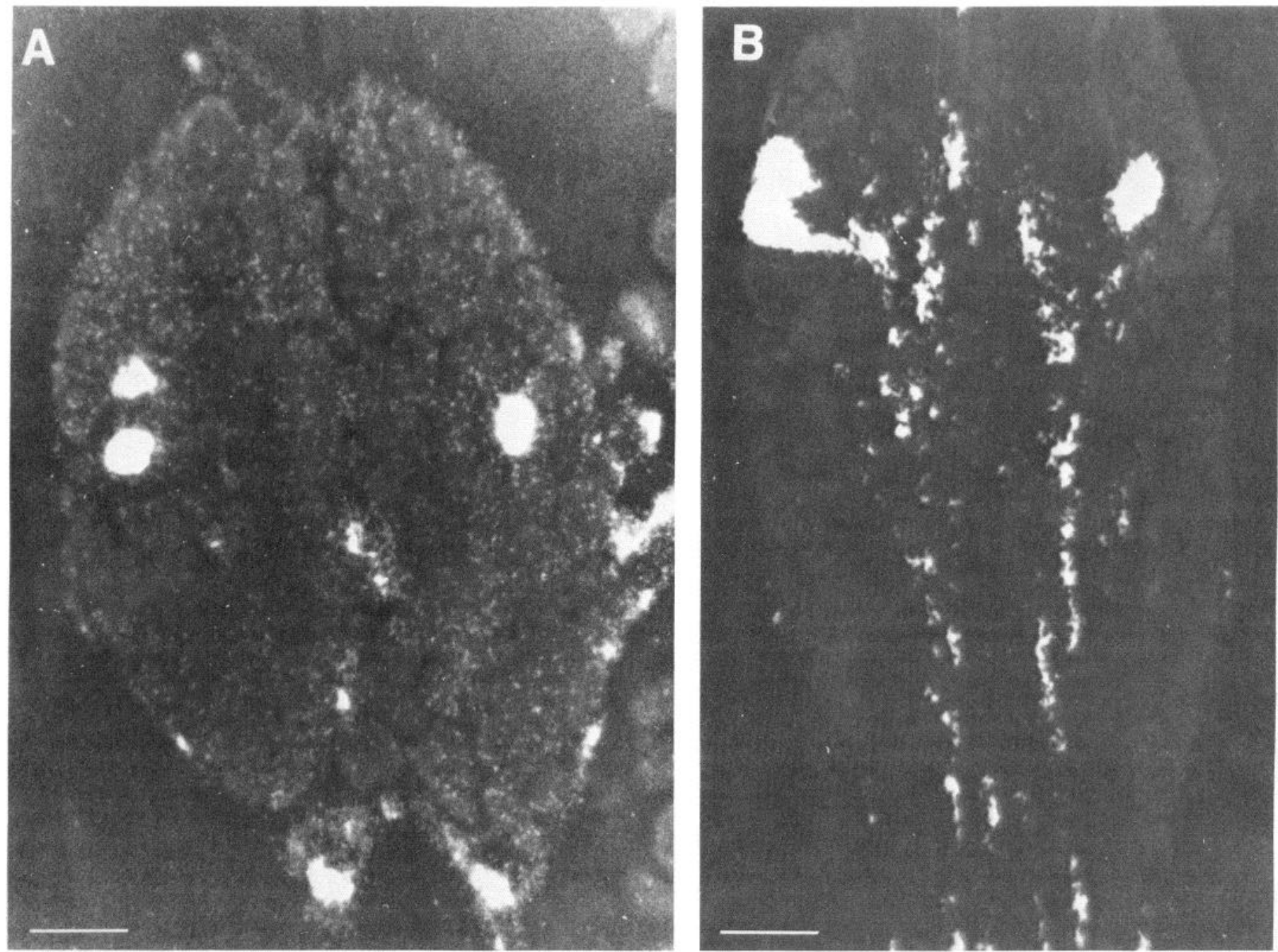

Figure 10. Autoradiographs of ${ }^{3} \mathrm{H}-\mathrm{GABA}-\mathrm{labeled}$ embryonic ganglia. Each section is part of a series cut every 1-2 $\mu \mathrm{m}$. $A$, Stage $9(3 / 4)$ : Cell bodies without processes take up GABA. No labeled processes were evident in any of the sections through this ganglion. $B$, Stage 10(4/5): Cell bodies and extensive neuropilar processes take up GABA. Anterior is uppermost. Scale bars, $20 \mu \mathrm{m}$.

system appears in more and more neurons in each ganglion, so that by stage $11(0)$ it is present in about 20 of them per ganglion (Fig. 9). By this time, there is also extensive uptake of ${ }^{3} \mathrm{H}-\mathrm{GABA}$ into neuropilar processes and axons of the major nerve tracts (Fig. 10B). The full adult complement of about 30 neurons per ganglion taking up GABA is reached by stage $11(5 / 20)$, at which time cells in the connective tissue capsule surrounding the ganglion also take up GABA.

\section{Discussion}

The observations presented here demonstrate that the capacity of the embryonic leech nervous system for synthesis and uptake of neurotransmitters appears during the first half of stage 9, when early gangliogenesis is under way (Fernandez, 1980; Kuwada and Kramer, 1983; Torrence and Stuart, 1986). By the end of stage 9 , outgrowth of neurites from the neuronal cell bodies has begun throughout the germinal plate, and the segmental and connective nerves are well established in the anterior segments. At about the same time, the ganglionic neuroblasts, which have been electrically passive hitherto, begin to respond actively to intracellular passage of depolarizing current, first with delayed rectification and later with an all-or-none depolarizing transient (Kuwada and Kramer, 1983; Kuwada, 1984). Thus, neurite outgrowth, as well as the appearance of proteins capable of gating ion currents and of biosynthetic systems dedicated to neurotransmitter formation, all occur within 3-4 d, i.e., within a relatively narrow window of developmental time.

Further maturation of neurotransmitter metabolism is probably correlated with the development of synapses in the ganglion. During stages 10 and 11 spontaneous excitatory and inhibitory synaptic potentials first appear and then become more frequent (Kuwada and Kramer, 1983), and the number of dopamine processes in the neuropil increases (Figs. 5 and 6), as does the number of 5-HT processes (D. K. Stuart and J. C. Glover, unpublished observations). In addition, the increase in the capacity to synthesize $\mathrm{ACh}$ is paralleled by the capacity to hydrolyze it after release, as can be shown by staining of the embryonic nerve cord of Helobdella triserialis for AChE (Fitzpatrick-McElligott and Stent, 1981). At the end of stage 9, ganglia contain little or no AChE. During stage 10, however, that enzyme appears in the neuropil of the ganglia, concomitantly with the rise of both the content of and the capacity to synthesize ACh.

During embryonic development, the specific content and spe- 
Figure 11. Summary diagram of the rostrocaudal development of the GABA uptake system in neurons of ganglia $11-18$ of a stage $9(3 / 4)$ embryo. The labeled neurons were identified in autoradiographs of serial sections through embryonic ganglia. Diagrammatic representations as in Figures 8 and 9 . $A$, Ganglion 11 . This ganglion is the most advanced developmentally in this series and contains more labeled neurons than the ganglia posterior to it. $B$, Ganglia 12-16. Note that the unpaired neuron on the ventral aspect and one of the pairs on the dorsal aspect, which take up label in ganglion 11, are not labeled in these ganglia. $C$, Ganglia 17 and 18, the least advanced developmentally in this series. Only 1 pair of neurons is labeled.
A
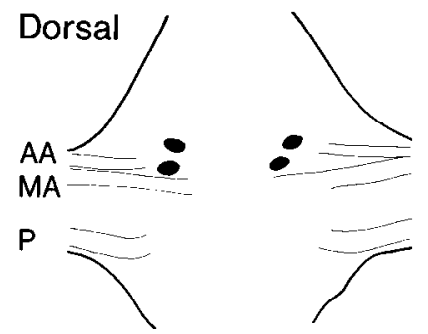

$P$
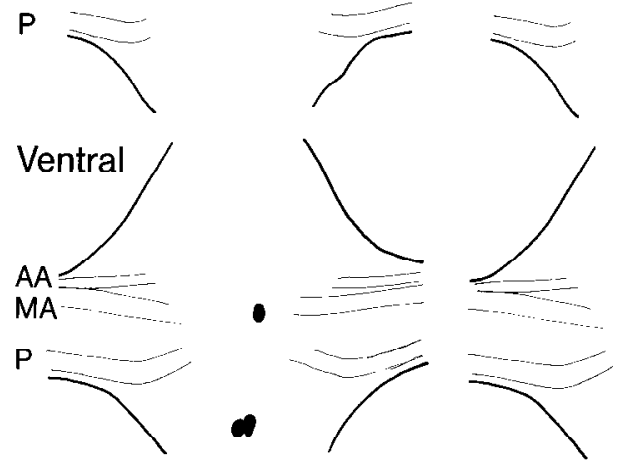

B
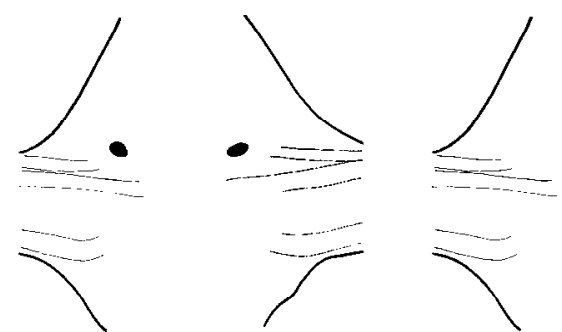

C
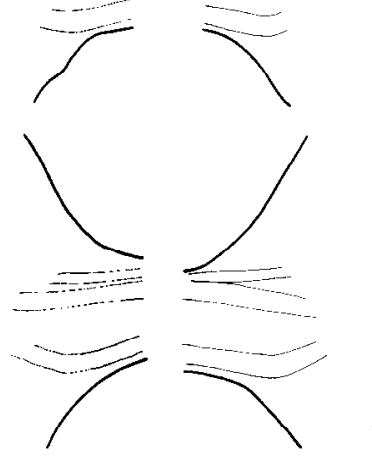
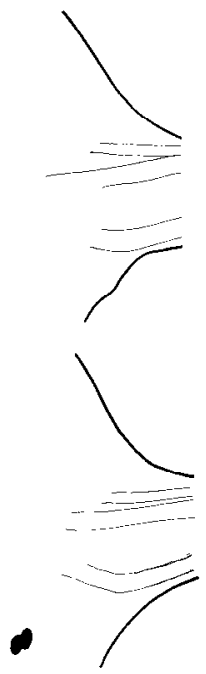

cific capacity for synthesis and accumulation of ACh and 5-HT relative to total protein content increase. Thus, the overall increase in metabolism of these transmitters does not result simply from general tissue growth, but may also reflect an increase in neurotransmitter concentration and synthetic capacity at the level of individual ACh- and 5-HT-containing neurons. Part of the increase in specific neurotransmitter content and synthetic capacity may also be attributable to a faster growth of $\mathrm{ACh}$ and 5-HT-containing neurons relative to other cells in the ganglia. In support of this latter possibility is the observation (Wallace, 1981) that the specific aromatic acid decarboxylase activity relative to protein content in extracts of individual Retzius cell somata isolated from $H$. medicinalis embryos is similar at different embryonic stages, suggesting that the concentration of 5-HT in these neurons may remain constant. In contrast to the considerable rise in the nerve cord, the much more moderate concurrent rise in specific ACh and 5-HT content of the body wall suggests that the increase in total body wall content of these neurotransmitters is attributable simply to the extension and branching of axons in order to maintain a given density in an expanding periphery.

The limited sensitivities of our assays make it difficult to time the precise onset of ACh, 5-HT, or dopamine metabolism, and hence to determine whether the expression of 1 neurotransmitter phenotype begins before that of another. It is clear, however, that these 3 neurotransmitters differ quantitatively with respect to their metabolism throughout the embryonic and postembryonic stages examined. From stage 9(1/4) to stage 11(2/20) the specific ACh content of the nerve cord exceeds that of 5-HT, which, in turn, exceeds that of dopamine, at least from stage 10(0). Similarly, in the grasshopper embryo ACh content reaches detectable levels before the octopamine and 5-HT contents (Goodman et al., 1979; Taghert and Goodman, 1984).

However, the initial predominance of ACh in the leech embryo is progressively diminished by increases in other neurotransmitters. Thus, whereas in the stage $10(0)$ nerve cord the ratio of the specific ACh content to the specific 5-HT content is $15: 1$, by stage $11(2 / 20)$, when the specific ACh content is nearing its maximum value, that ratio has fallen to $5: 1$. In the unfed juvenile nerve cord, 5-HT is more abundant than ACh,

and in the adult leech nerve cord, where the specific ACh content is less than half of its embryonic peak value and the specific 5-HT content has risen to nearly twice its value in the unfed juvenile nerve cord, 5-HT predominates over ACh by a factor of 5:1. Similarly, the ratio of specific ACh content to specific dopamine content is $29: 1$ at stage 11(2/20) but falls to about $3: 1$ in the unfed juvenile and is only about $2: 1$ in the adult nerve cord.

The early appearance of neurotransmitter metabolism suggests that in embryonic leech tissues neurotransmitters may function in a capacity other than synaptic transmission, as had been previously suggested by Fitzpatrick-McElligott and Stent (1981), who found AChE activity at the very earliest stages of lecch development, well before neurogenesis. Neurotransmitters have been implicated in the regulation of both organismal and neural development (Buznikov et al., 1968; Kusano et al., 1977; Lauder and Krebs, 1978). In a recent example, Haydon et al. (1984) have demonstrated that 5-HT influences the growth cone motility of some cultured neurons, thereby regulating growth and synaptogenesis.

The changing relationship between $\mathrm{ACh}$ and 5-HT levels has an interesting correlate in behavioral ontogeny. The first neurally controlled behavior manifest in the leech embryo is a simple body-shortening reflex, which would be expected to depend on the release of ACh by motor neurons. This reflex appears during the latter part of stage 10, when ACh is the predominant neurotransmitter (Weisblat, 1981). The more complex swimming movement, which is modulated by the 5-HT level of the blood (Willard, 1981) and for which the presence of 5-HT in the nervous system is a necessary condition (Glover and Kramer, 1982), appears no sooner than about stage 11(10/20) (Glover, 1984), by which time 5 -HT content and ACh content are comparable. The proposed neurohumoral role of 5-HT released by 5-HT neurons (Willard, 1981; Kristan and Nusbaum, 1983) is compatible with a continuing rise in the specific 5-HT content of the nerve cord into adult life, since with each feeding the overall size of the leech, and hence the volume of its body fluids, increases by a much greater factor than the size, and hence the total protein, of its nerve cord (Sawyer et al., 1981). Moreover, this preponderance of 5-HT over ACh in the adult occurs despite 
the fact that the leech has 3 times as many ACh motor neurons as 5-HT neurons (Wallace, 1981).

The data presented here for the development of the capacity to synthesize and accumulate GABA cannot be directly compared with the data for ACh and 5-HT because of methodological differences. First, the assays of the capacity for $\mathrm{ACh}$ and 5-HT synthesis measured only the amounts of labeled neurotransmitter accumulated within the nerve cord, whereas the assays of the capacity for GABA synthesis also measured the amounts released into the incubation medium. Second, the concentration of the ${ }^{3} \mathrm{H}$-labeled precursor present in the incubation mixture was 125-200 times higher in the GABA assays than in the ACh and 5-HT assays. Nevertheless, there does seem to be a significant difference between the development of the metabolism of GABA and that of the metabolism of the other neurotransmitters: between stages $9(1 / 4)$ and $11(2 / 20)$ the capacity for GABA synthesis and accumulation increases only 3- to 4-fold, in contrast to the 60- to 75-fold increases observed for $\mathrm{ACh}$ and 5-HT, respectively, during the same period. Moreover, the spccific capacity for GABA synthesis and accumulation relative to the protein content of the nerve cord actually decreases during stage 11, despite the concurrent increase in the number of neurons taking up GABA. This difference between the development of the metabolism of GABA, on the one hand, and of ACh and 5-HT, on the other, could be due to differential increases in the rates of either synthesis, release, or breakdown of these neurotransmitters.

The developmental stage at which the GABA uptake system is expressed varies from neuron to neuron within the same ganglion, so that some neurons manifest the uptake system at the beginning and other neurons manifest it only at the end of the 12-15 d period during which the nerve system matures. A similar, neuron-specific spectrum of the beginning of neurotransmitter uptake (albeit spread over a shorter period of time) has becn observed for the uptake of 5-HT by the 5-HT neurons (D. K. Stuart and J. C. Glover, unpublished observations). Some precocious neurons probably take up GABA before they extend neurites, and hence before they have formed synapses. In this respect they resemble some immature, migrating neurons in the embryonic vertebrate cerebellum, which can take up GABA before they reach their definitive cortical positions or form synapses (Hatten et al., 1984).

Some of the neurons of the embryonic leech nerve cord thus develop the capacity for ACh, 5-HT, and GABA metabolism as one of their earliest differentiated phenotypic characteristics. In this respect they resemble the developing neurons of several vertebrate and invertebrate species, which express their neurotransmitter phenotype at an early stage of differentiation, before most of their morphological development occurs and before they contact their target cells (Hyde and Robinson, 1974; Sanes and Hildebrand, 1975a, b; Bondy and Purdy, 1977; Prescott et al., 1977; Rothman et al., 1978; Hatten et al., 1984; Berardi and Concetta, 1985). It is possible, therefore, that the neurotransmitters in these embryonic neurons play some functional role before or during neurite outgrowth. However, in the case of the dopamine-containing neurons of the embryonic leech PNS, just as in the case of the octopamine-, 5-HT-, and proctolin-containing neurons of the grasshoppcr CNS (Goodman et al., 1979; Taghert and Goodman, 1984; Keshishian and O'Shea, 1985), the differentiation of neurotransmitter metabolism is first apparent only after extensive neurite outgrowth and may there- fore be more closely related to the establishment of synaptic connections during the later stages of morphological development.

\section{References}

Beltz, B. S., and E. A. Kravitz (1983) Mapping of serotonin-like immunoreactivity in the lobster nervous system. J. Neurosci. 3: 585602.

Berardi, N., and M. M. Concetta (1985) Development of aminobutyric acid mediated inhibition of $X$ cells of the cat lateral geniculate nucleus. J. Physiol. (Lond.) 357: 525-538.

Blair, S. S. (1983) Blastomere ablation and the developmental origin of identified monoamine-containing neurons in the leech. Dev. Biol. 95: 65-72.

Bondy, S. C., and J. L. Purdy (1977) Putative neurotransmitters of the avian visual pathway. Brain Res. 119: 417-426.

Buznikov, G. A., I. V. Chudakova, L. V. Berdychwa, and N. M. Vyazmina (1968) The role of neurohumors in early embryogenesis. II. Acetylcholine and catecholamine in developing embryos of sea urchins. J. Embryol. Exp. Morphol. 20: 119-128.

Cline, H. T. (1983) ${ }^{3}$ H-GABA uptake selectively labels identifiable neurons in the leech central nervous system. J. Comp. Neurol. 215: 351-358.

Cline, H. T. (1986) Evidence for GABA as a neurotransmitter in the leech. J. Neurosci. 6: 2848-2856.

Cline, H. T., M. P. Nusbaum, and W. B. Kristan, Jr. (1985) Identified GABA-ergic inhibitory motor neurons in the leech central nervous system take up GABA. Brain Res. 385: 359-362.

Coggeshall, R. E., S. A. Dewhurst, D. Weinreich, and R. E. McCaman (1972) Aromatic acid decarboxylase and acetylase activities in a single identified 5-HT containing cell of the leech. J. Neurobiol. 3: 259-265.

de la Torre, J. C., and J. W. Surgeon (1976) A methodological approach to rapid and sensitive monoamine histofluorescence using a modified glyoxylic acid technique: The SPG method. Histochemistry 49: 8193.

Fernandez, J. (1980) Embryonic development of the glossiphoniid leech Theromyzon rude: Characterization of developmental stages. Dev. Biol. 76: 245-262.

Fitzpatrick-McElligott, S., and G. S. Stent (1981) Appearance and localization of acetylcholinesterase in embryos of the leech Helobdella triserialis. J. Neurosci. 1: 901-907.

Gillon, J. W., and B. G. Wallace (1984) Segmental variation in the arborization of identified neurons in the leech central nervous system. J. Comp. Neurol. 228: 142-148.

Glover, J. C. (1984) Structure, function and development of serotonincontaining neurons in the leech. Ph.D. thesis, University of California, Berkeley.

Glover, J.C. (1987) Serotonin storage and uptake by identified neurons in the leech Haementeria ghilianii. J. Comp. Neurol. (in press).

Glover, J. C., and A. P. Kramer (1982) Serotonin analog selectively ablates identified neurons in the leech embryo. Science 216:317-319.

Goldberg, A. M., and R. E. McCaman (1973) The determination of picomole amounts of acetylcholine in mammalian brain. J. Neurochem. 20: $1-8$.

Goodman, C. S., M. O'Shea, R. McCaman, and N. C. Spitzer (1979) Embryonic development of identified neurons: Temporal pattern of morphological and biochemical differentiation. Science 204: 12191222 .

Granzow, B., W. O. Friesen, and W. B. Kristan, Jr. (1985) Physiological and morphological analysis of synaptic transmission between leech motor neurons. J. Neurosci. 5: 2035-2050.

Hatten, M. B., A. M. Francois, E. Napolotano, and S. Roffler-Tarlov (1984) Embryonic cerebellar neurons accumulate ${ }^{3} \mathrm{H}$-gamma-aminobutyric acid: Visualization of developing-aminobutyric acid-utilizing neurons in vitro and in vivo. J. Neurosci. 4: 1343-1353.

Haydon, P. G., D. P. McCobb, and S. B. Kater (1984) Serotonin selectively inhibits growth cone motility and synaptogenesis of specific identified neurons. Science 226: 561-564.

Hildebrand, J. G., D. L. Barker, E. Herbert, and E. A. Kravitz (1971) Screening for neurotransmitters: A rapid radiochemical procedure. J. Neurobiol. 2: 231-246.

Hyde, J. C., and N. Robinson (1974) Appearance of gamma amino- 
butyrate transaminase activity in developing rat brain. J. Neurochem. 23: $365-367$.

Keshishian, H., and M. O'Shea (1985) The acquisition and expression of a peptidergic phenotype in the grasshopper embryo. J. Neurosci. 5: 1005-1015.

Kramer, A. P., and J. R. Goldman (1981) The nervous system of the glossiphoniid leech Haementeria ghilianii. I. Identification of neurons. J. Comp. Physiol. 144: 435-448.

Kramer, A. P., and J. Y. Kuwada (1983) Formation of the receptive fields of leech mechanosensory neurons during embryonic development. J. Neurosci. 3: 2474-2486.

Kramer, A. P., and D. A. Weisblat (1985) Development of neuronal kinship groups in the leech. J. Neurosci. 5: 388-407.

Kristan, W. B., Jr., and M. P. Nusbaum (1983) The dual role of serotonin in leech swimming. J. Physiol. (Paris) 78: 743-747.

Kuhlman, J. R., R. L. Calabrese, and C. Li (1984) FMRFamide-like substances in the leech: Immunocytochemical localization. Soc. Neurosci. Abstr. 10: 151.

Kusano, K., R. Miledi, and J. Stinnakre (1977) Acetylcholine receptors in oocyte membrane. Nature 207: 739-741.

Kuwada, J. Y. (1984) Normal and abnormal development of an identified leech motor neuron. J. Embryol. Exp. Morphol. 79: 125-137.

Kuwada, J. Y., and A. P. Kramer (1983) Embryonic development of the leech nervous system: Primary axon outgrowth of identified neurons. J. Neurosci. 3: 2098-2111.

Lauder, J. M., and H. Krebs (1978) Serotonin as a differentiation signal in early neurogenesis. Dev. Neurosci. $1: 15-30$.

Leake, L. D., R. Crowe, and G. Burnstock (1986) Localization of substance P-, somatostatin-, vasoactive intestinal polypeptide- and met-enkephalin-immunoreactive nerves in the peripheral and central nervous systems of the leech (Hirudo medicinalis). Cell Tissue Res. 243: 345-351.

Lent, C. M. (1982) Fluorescent properties of monoamine neurons following glyoxylic acid treatment of intact leech ganglia. Histochemistry 75: 77-89.

Lent, C. M., R. L. Mueller, and D. A. Haycock (1983) Chromatographic and histochemical identification of dopamine within an identified neuron in the leech nervous system. J. Neurochem. 41: 481490.

Li, C., and R. L. Calabrese (1985) Evidence for proctolin-like substances in the central nervous system of the leech Hirudo medicinalis. J. Comp. Neurol. 232: 414-424.

Lindvall, O., A. Bjorklund, and L.-A. Svensson (1974) Fluorophore formation from catecholamines and related compounds in the glyoxylic acid fluorescence histochemical method. Histochemistry 39: 197227.

Lowry, O. H., N. J. Rosebrough, A. L. Farr, and R. J. Randall (1951) Protein measurement with the Folin phenol reagent. J. Biol. Chem. 193: 844-847.

Mains, R. E., and P. H. Patterson (1973) Primary cultures of dissociated sympathetic neurons. I. Establishment of long-term growth in culture and studies of differentiated properties. J. Cell Biol. 59: 329345.

McAdoo, D. J., and R. E. Coggeshall (1976) Gas chromatographicmass spectrometric analysis of biogenic amines in identified neurons and tissues of Hirudo medicinalis. J. Neurochem. 26: 163-167.

McCaman, M. W., and R. E. McCaman (1978) Octopamine and phenylethanolamine in Aplysia ganglia and in individual neurons. Brain Res. 141: 347-352.

McCaman, M. W., D. Weinreich, and R. E. McCaman (1973) The determination of picomole levels of 5-hydroxytryptamine and dopamine in Aplysia, Tritonia and leech nervous tissues. Brain Res. 53: 129-137.

McCaman, M. W., R. E. McCaman, and J. Stetzler (1979) A rapid radioenzymatic assay for dopamine and $N$-acetyldopamine. Anal. Biochem. 96: 175-180.

McCaman, M. W., J. K. Ono, and R. E. McCaman (1984) 5-hydroxytryptamine measurements in molluscan ganglia and neurons using a modified radioenzymatic assay. J. Neurochem. 43: 91-99.

McCaman, R. E. (1971) Quantitative isotopic methods for measuring enzyme activities and endogenous substrate levels. In International Encyclopedia of Pharmacology and Therapeutics: Section 78, Radionuclides in Pharmacology. Vol. 1, Y. Cohen, ed., pp. 275-314, Pergamon, Oxford.
McCaman, R. E., and J. Stetzler (1977) Radiochemical assay for ACh: Modifications for sub-picomole measurements. J. Neurochem. 28: $669-671$.

Ono, J. K., and R. E. McCaman (1984) Immunocytochemical localization and direct assays of serotonin-containing neurons in Aplysia. Neuroscience 11: 549-560.

Peterson, G. L. (1977) A simplification of the protein assay method of Lowry et al. which is more generally applicable. Anal. Biochem: 83: 346-356.

Prescott, D. J., J. G. Hildebrand, J. R. Sanes, and S. Jewett (1977) Biochemical and developmental studies of acetylcholine metabolism in the central nervous system of the moth Manduca sexta. Comp. Biochem. Physiol. 56C: 77-84.

Rothman, T. P., M. D. Gershon, and M. Holtzer (1978) The relationship of cell division to the acquisition of adrenergic characteristics. Dev. Biol. 65: 322-341.

Sanes, J. R., and J. G. Hildebrand (1976a) Origin and morphogenesis of sensory neurons in an insect antenna. Dev. Biol. 51: 300-319.

Sanes, J. R., and J. G. Hildebrand (1976b) Acetylcholine and its metabolic enzymes in developing antennae of the moth, Manduca sexta. Dev. Biol. 52: 105-120.

Sargent, P. B. (1977) Synthesis of acetylcholine by excitatory motoneurons in central nervous system of the leech. J. Neurophysiol. 40: 453-460.

Sawyer, R. T., F. LePont, D. K. Stuart, and A. P. Kramer (1981) Growth and reproduction of the giant glossiphoniid leech Haementeria ghilianii. Biol. Bull. 160: 322-331.

Steinbusch, H. W. M., A. A. J. Verhofstad, and H. W. J. Joosten (1978) Localization of serotonin in the central nervous system by immunohistochemistry: Description of a specific and sensitive technique and some applications. Neuroscience 3: 811-819.

Steinbusch, H. W. M., A. A. J. Verhofstad, and H. W. J. Joosten (1983) Antibodies to serotonin for neuroimmunocytochemical studies: Methodological aspects and applications. In Immunohistochemistry, A. C. Cuello, ed., pp. 193-214, Wiley, Chichester, U.K.

Stent, G. S., D. A. Weisblat, S. S. Blair, and S. L. Zackson (1982) Cell lineage in the development of the leech nervous system. In Neuronal Development, N. C. Spitzer, ed., pp. 1-44, Plenum, New York.

Stuart, A. E., A. J. Hudspeth, and Z. W. Hall (1974) Vital staining of specific monoamine-containing cells in the leech nervous system. Cell Tissue Res. 153: 55-61.

Stuart, D. K. (1981) Monoamine neurons in embryonic and adult leech. Soc. Neurosci. Abstr. 7: 2.

Stuart, D. K., S. S. Blair, and D. A. Weisblat (1987) Cell lineage, cell death and the developmental origin of identified serotonin- and dopamine-containing neurons in the leech. J. Neurosci. (in press).

Taghert, P. H., and C. S. Goodman (1984) Cell determination and differentiation of identified serotonin-immunoreactive neurons in the grasshopper embryo. J. Neurosci. 4: 989-1000.

Tapia, R. (1983) Regulation of glutamate decarboxylase activity. In Glutamine, Glutamate, and GABA in the Central Nervous System, $\mathrm{L}$. Hertz, E. Kramme, E. G. McGeer, and A. Schovsboe, eds., pp. 113128 , Liss, New York.

Torrence, S. A., and D. K. Stuart (1986) Gangliogenesis in leech embryos: Migration of neural precursor cells. J. Neurosci. 6: 2736-2746.

Wallace, B. G. (1981) Neurotransmitter chemistry. In Neurobiology of the Leech, K. J. Muller, J. G. Nicholls, and G. S. Stent, eds., pp. 147-172, Cold Spring Harbor Laboratory, Cold Spring Harbor, NY.

Weinreich, D., C. Weiner, and R. McCaman (1975) Endogenous levels of histamine in single neurons isolated from CNS of Aplysia californica. Brain Res. 84: 341-345.

Weisblat, D. A. (1981) Development of the nervous system. In Neurobiology of the Leech, K. J. Muller, J. G. Nicholls, and G. S. Stent, eds., pp. 173-195, Cold Spring Harbor Laboratory, Cold Spring Harbor, NY.

Weisblat, D. A., G. Harper, G. S. Stent, and R. T. Sawyer (1980) Embryonic cell lineages in the nervous system of the glossiphoniid leech Helobdella triserialis. Dev. Biol. 76: 58-78.

Willard, A. L. (1981) Effects of serotonin on the generation of the motor program for swimming by the medicinal leech. J. Neurosci. I: 936-944.

Zipser, B. (1980) Identification of specific leech neurones immunoreactive to enkephalin. Nature $283: 857-858$. 